\title{
Pemanfaatan Kandungan Bioaktif Tanaman Lokal Untuk Menunjang Produktifitas Ternak Unggas (Ulasan)
}

\author{
Didik Nur Edi \\ Seksi Pembibitan Ternak dan Hijauan Makanan Ternak \\ UPT Pembibitan Ternak dan Kesehatan Hewan di Madura \\ Dinas Peternakan Provinsi Jawa Timur, Pamekasan 69383, Jawa Timur, Indonesia \\ Email: didiknuredi@yahoo.co.id
}

\section{Tersedia Online di}

http://www.jurnal.unublitar.ac.id/i ndex.php/briliant

\begin{tabular}{l}
\hline Sejarah Artikel \\
\hline Diterima pada 8 September 2020 \\
Disetujui pada 26 November 2020 \\
Dipublikasikan pada 30 November \\
2020
\end{tabular}

Hal. 819-838

\begin{tabular}{l}
\hline Kata Kunci: \\
\hline Imbuhan pakan; kandungan \\
bioaktif; level penggunaan; \\
tanaman lokal \\
\hline
\end{tabular}

DOI:

http://dx.doi.org/10.28926/briliant. v3i4.543

\begin{abstract}
Abstrak: Penulisan artikel ini bertujuan untuk memberikan gambaran secara umum kandungan bioaktif pada tanaman lokal, daya hambat bakteri, cara aplikasi, batasan penggunaan, dampak pada produktifitas ternak unggas dan profitabiltas peternak. Ulasan ini diharapkan dapat membantu para pembaca dan praktisi dalam memilih dan membandingkan tanaman lokal yang berkhasiat yang mudah terjangkau di lingkungannya untuk dapat dimanfaatkan. Hasil dari ulasan artikel ini adalah beberapa tanaman lokal di Indonesia dapat digunakan sebagai imbuhan pakan dan sebagian lainnya dapat digunakan sebagai bahan pakan alternatif. Tanaman lokal pada level dan aplikasi yang tepat dapat meningkatkan produktifitas ternak unggas. Level penggunaan bentuk tepung relatif lebih tinggi dari pada ekstrak. Kandungan bioaktif utama tanaman lokal adalah fenol, flavonoid, antosianin, minyak atsiri dan asam organik. Kandungan bioaktif tersebut secara umum mempunyai sifat antimikroba, antioksidan, antijamur dan zat warna alami. Pemanfaatan tanaman lokal dapat menunjang kemandirian usaha peternakan.
\end{abstract}

\section{PENDAHULUAN}

Pakan yang berkualitas diperlukan untuk menunjang produktifitas ternak unggas menjadi optimal sesuai dengan potensi genetiknya. Upaya peningkatan kualitas pakan salah satunya adalah dengan penambahan imbuhan pakan. Penambahan imbuhan pakan ternak unggas pada umumnya berupa antibiotik atau dikenal luas dengan antibiotic growth promotor (AGP), prebiotik, probiotik, enzim, asam organik dan bioaktif tanaman (fitobiotik). Imbuhan pakan berupa AGP digunakan pada ayam petelur untuk meningkatkan produktifitas, meningkatkan efisiensi penggunaan pakan dan menjaga kesehatan ternak (Cervantes, 2012). Menurut Magdalena et al. (2013), antibiotik berfungsi untuk membantu melawan bakteri pathogen sehingga dapat meningkatkan produksi ternak unggas. Pemanfaatan antibiotik di Indonesia, dibatasi penggunaannya, hanya untuk terapi ternak sakit dan untuk AGP telah dilarang yang tertuang dalam PERMANTAN RI No. 14/PERMENTAN/PK.350/5/2017 pasal 16 ayat 2 tentang Klasifikasi Obat Hewan.

Zurmiati dkk., (2014) menyatakan bahwa para ahli kesehatan masyarakat memperkirakan penggunaan antibiotik pada level sub-therapeutic sebagai AGP, kemungkinan besar merupakan penyebab berkembangnya populasi bakteri yang resisten terhadap suatu antibiotik. Kasus cemaran antibiotik masih banyak ditemukan di 
Indonesia, residu tersebut ditemukan pada daging dan hati ayam berupa antibiotik jenis sulfa, oksitetrasiklin, enrofloksasin, tetrasiklin, siprofloksasin dan makrolida (Etikaningrum dan Iwantoro, 2017). Residu antibiotik pada produk ternak dapat mengakibatkan resisten pada tubuh ternak, resiko kurang baik bagi kesehatan manusia apabila mengkonsumsi produk tersebut, resisten pada bakteri patogen seperti Campylobacter, Salmonella, Enterococcus dan Escherichia coli (Graham et al., 2007).

Salah satu alternatif yang dapat dilakukan untuk mengurangi penggunaan antibiotik dengan tetap menjaga produkstifitas ternak unggas adalah dengan memanfaatkan kandungan bioaktif tanaman lokal. Tanaman lokal di Indonesia banyak sekali yang mempunyai khasiat seperti obat (Jumiarni \& Komalasari, 2017). Phytogenic feed additives dapat berasal dari herbal atau fitobiotik pada perlakuan tradisional (Gheisar \& Kim, 2018). Ramiah et al., (2014) menambahkan fitobiotik adalah tanaman herbal yang memiliki bahan aktif yang dapat bersifat antibakteri dapat memperbaiki kondisi saluran pencernaan (keseimbangan $\mathrm{pH}$ dan mikroflora), memperbaiki konversi pakan, meningkatkan kecernaan zat-zat makanan dan meningkatkan produktifitas ternak.

Penulisan artikel ini bertujuan untuk memberikan gambaran secara umum kandungan bioaktif pada tanaman lokal, cara aplikasi, batasan penggunaan dan dampak pada produktifitas ternak unggas. Artikel ini merupakan ulasan dari berbagai literatur yang masih tersebar untuk dijadikan satu bacaan. Ulasan ini diharapkan dapat membatu para pembaca dan praktisi ternak unggas dalam memilih dan membandingkan tanaman lokal yang berkhasiat yang mudah terjangkau di lingkungannya untuk dapat manfaatkan untuk imbuhan atau bahan pakan alternatif.

\section{PEMBAHASAN}

\section{Kandungan bioaktif}

Tanaman lokal di Indonesia banyak yang mengadung bioaktif alami seperti flavonoid, fenol, antosianin, antioksidan, asam organik dan minyak atsiri (Pasaribu, 2019). Kandungan bioaktif tersebut mempunyai beragam manfaat diantaranya adalah antibakteri, antioksidan, zat warna, acidifier (menjaga kondisi $\mathrm{pH}$ saluran pencernaan) dan merangsang enzim pencernaan (Edi, 2018; Natsir dkk., 2016; Sari, 2016). Kandungan bioaktif beberapa tanaman lokal yang sering digunakan untuk imbuhan pakan ternak unggas disajikan pada Tabel 1.

Tabel 1. Kandungan bioaktif dan manfaat tanaman lokal di Indonesia

\begin{tabular}{|c|c|c|c|c|c|}
\hline No & Nama lokal & Nama ilmiah & Kandungan bioaktif & Manfaat & Sumber \\
\hline 1 & $\begin{array}{l}\text { Bawang } \\
\text { putih }\end{array}$ & $\begin{array}{l}\text { Allium } \\
\text { sativum } \mathrm{L} .\end{array}$ & $\begin{array}{l}\text { Ekstrak } \\
\text { - Flavonoid 58,03 mg/kg } \\
\text { - Fenol 78,66 mg/kg } \\
\text { - Allicin 20,73-24,31 mg/g }\end{array}$ & $\begin{array}{l}\text { - Antibakteri } \\
\text { - Antioksidan }\end{array}$ & $\begin{array}{l}\text { Prati et al., } 2014 \\
\text { Yuniarti dkk., } \\
2018\end{array}$ \\
\hline 2 & $\begin{array}{l}\text { Bawang } \\
\text { merah }\end{array}$ & $\begin{array}{l}\text { Allium cepa } \mathrm{L} . \\
\text { var. aggregatu } \\
m\end{array}$ & $\begin{array}{l}\text { Ekstrak } \\
\text { - Flavonoid 134,63 mg/kg } \\
\text { - Fenol } 341,96 \mathrm{mg} / \mathrm{kg}\end{array}$ & $\begin{array}{l}\text { - Antibakteri } \\
\text { - Antioksidan }\end{array}$ & $\begin{array}{l}\text { Yuniarti dkk., } \\
2018\end{array}$ \\
\hline 3 & $\begin{array}{l}\text { Biji } \\
\text { ketumbar }\end{array}$ & $\begin{array}{l}\text { Coriandrum } \\
\text { sativum Linn }\end{array}$ & $\begin{array}{l}\text { Tepung } \\
\text { - Minyak atsiri } 10.000 \mathrm{mg} / \mathrm{kg} \\
\text { terdiri atas linalool } 67,7 ; \alpha- \\
\text { pinene } 10,5 ; \gamma \text {-terpinene } 9,0 \text {; } \\
\text { geranyl asetat } 4,0 ; \text { kamper } \\
\text { 3,0 dan geraniol } 1,9 \% \text {. }\end{array}$ & $\begin{array}{l}\text { - Antibakteri } \\
\text { - Antimikroba } \\
\text { - Antibiotik }\end{array}$ & Habiyah, 2015 \\
\hline 4 & $\begin{array}{l}\text { Blimbing } \\
\text { wuluh }\end{array}$ & $\begin{array}{l}\text { Averrhoa } \\
\text { bilimbi L. }\end{array}$ & $\begin{array}{l}\text { Tepung } \\
\text { - Asam sitrat 92-133 meq }\end{array}$ & $\begin{array}{l}\text { - Acidifier } \\
\text { - Menjaga pH saluran }\end{array}$ & $\begin{array}{l}\text { Prahardi dkk., } \\
2018\end{array}$ \\
\hline
\end{tabular}

820 BRILIANT: Jurnal Riset dan Konseptual Volume 5 Nomor 4, November 2020 


\begin{tabular}{|c|c|c|c|c|c|}
\hline No & Nama lokal & Nama ilmiah & Kandungan bioaktif & Manfaat & Sumber \\
\hline & & & $\begin{array}{l}\text { asam/100 gr total padatan } \\
\text { - Asam laktat } 0,4-1,2 \text { meq } \\
\text { asam/100 gr total padatan }\end{array}$ & $\begin{array}{l}\text { pencernaan } \\
\text { - Menekan bakteri } \\
\text { patogen }\end{array}$ & $\begin{array}{l}\text { Tristianti dkk., } \\
2018\end{array}$ \\
\hline 5 & $\begin{array}{l}\text { Buah } \\
\text { mengkudu }\end{array}$ & $\begin{array}{l}\text { Morinda } \\
\text { citrifolia }\end{array}$ & $\begin{array}{l}\text { Ampas } \\
\text { - Antrakinon } 12.000 \mathrm{mg} / \mathrm{kg}\end{array}$ & $\begin{array}{ll}\text { - } & \text { Peredam cekaman } \\
& \text { stres } \\
\text { - } & \text { Antibakteri } \\
\text { - } & \text { Antioksidan }\end{array}$ & $\begin{array}{l}\text { Bintang dkk., } \\
2008 \\
\text { Nurhayati, } 2008\end{array}$ \\
\hline 6 & Buah tomat & $\begin{array}{l}\text { Lycopersicon } \\
\text { esculentum } \\
\text { Miller }\end{array}$ & $\begin{array}{l}\text { Segar } \\
\text { - Flavonoid } 105,1 \mathrm{mg} / \mathrm{kg} \\
\text { - Karotenoid } 80-90 \% \\
\text { - } \beta \text { karoten } 7-10 \% \\
\text { - Likopen } 1 \mathrm{mg} / \mathrm{g} \\
\text { - } \text { Vit C } 21 \mathrm{mg} / \mathrm{g} \\
\end{array}$ & $\begin{array}{l}\text { - Penurun kolesterol } \\
\text { - Antioksidan }\end{array}$ & $\begin{array}{l}\text { Cao et al., } 2010 \\
\text { Akademir et al., } \\
2012 \\
\text { Timbuleng et } \\
\text { al., } 2015\end{array}$ \\
\hline 7 & Daun afrika & $\begin{array}{l}\text { Vernonia } \\
\text { amydalina }\end{array}$ & $\begin{array}{l}\text { Ekstrak } \\
\text { - Fenol } 1,58 \mathrm{mg} / \mathrm{g} \mathrm{BK} \\
\text { - Flavonoid } 0,85 \mathrm{mg} / \mathrm{g} \mathrm{BK} \\
\text { - Antosianin } 0,09 \mathrm{ng} / \mathrm{g} \mathrm{BK} \\
\text { - Tanin } 1,18 \mathrm{mg} / \mathrm{Kg} \mathrm{BK} \\
\text { - Antioksidan } 1,83 \mathrm{mg} / \mathrm{ml}\end{array}$ & $\begin{array}{l}\text { - Antibakteri } \\
\text { - Antioksidan } \\
\text { - Antitumor }\end{array}$ & $\begin{array}{l}\text { Omede et al., } \\
2018\end{array}$ \\
\hline 8 & Daun jarak & $\begin{array}{l}\text { Jatropha } \\
\text { curcas }\end{array}$ & $\begin{array}{l}\text { Ekstrak } \\
\text { - Fenol 9,29 mg/g } \\
\text { - Saponin 0,37 mg/g } \\
\text { - Flavonoid } 0,91 \mathrm{mg} / \mathrm{g}\end{array}$ & Anticacing & $\begin{array}{l}\text { Namuli et al., } \\
2011\end{array}$ \\
\hline 9 & Daun jati & $\begin{array}{l}\text { Tectona } \\
\text { grandis Linn. } \\
\mathrm{F}\end{array}$ & $\begin{array}{l}\text { Ekstrak } \\
\text { - Antioksidan 47,61\% } \\
\text { - Antosianin } 83,89 \mathrm{ppm} \\
\text { - Flavonoid } 0,128 \% \\
\text { - Tanin } 129,79 \mathrm{mg} / \mathrm{ml} \\
\text { Tepung } \\
\text { - Antioksidan } 56,22 \% \\
\text { - Antosianin } 106,99 \mathrm{ppm} \\
\text { - Flavonoid } 0,165 \%\end{array}$ & $\begin{array}{l}\text { - Antibakteri } \\
\text { - Antioksidan } \\
\text { - Zat warna }\end{array}$ & $\begin{array}{l}\text { Edi, } 2018 \\
\text { Oka dkk., } 2016\end{array}$ \\
\hline 10 & Daun katuk & $\begin{array}{l}\text { Sauropus } \\
\text { androgynus }\end{array}$ & $\begin{array}{l}\text { Segar } \\
\text { - Flavonoid 0,143\% } \\
\text { - Fenol 1,43 mg/g } \\
\text { - Antioksidan 7,72 } \mu \mathrm{mol} \mathrm{TE} / \mathrm{g} \\
\text { - Vit C } 24400 \mathrm{mg} / \mathrm{g} \\
\text { - A-tokoferol } 426 \mathrm{mg} / \mathrm{kg} \\
\text { - Thiamin } 50 \mathrm{mg} / \mathrm{g} \\
\text { - Riboflavin } 21 \mathrm{mg} / \mathrm{g} \\
\text { Tepung } \\
\text {-Tanin } 0,46 \% \\
\text {-Saponin } 2,84 \%\end{array}$ & $\begin{array}{l}\text { - Antioksidan } \\
\text { - Antibakteri }\end{array}$ & $\begin{array}{l}\text { Santoso, } 2018 \\
\text { Hermana dkk., } \\
2013\end{array}$ \\
\hline 11 & Daun kelor & $\begin{array}{l}\text { Moringa } \\
\text { olievera }\end{array}$ & $\begin{array}{l}\text { Ekstrak metanol } \\
\text { - Flavonoid 8,1-9,6\% } \\
\text { - Fenol 2,5-3,0\% } \\
\text { - Quercetin 0,06 mg/g } \\
\text { - Antioksidan 134,5-146,7 } \\
\quad \mu \mathrm{g} / \mathrm{ml}\end{array}$ & Antioksidan & $\begin{array}{l}\text { Sulastri et al., } \\
2018\end{array}$ \\
\hline 12 & $\begin{array}{l}\text { Daun } \\
\text { mahkota } \\
\text { dewa }\end{array}$ & $\begin{array}{l}\text { Phaleria } \\
\text { macrocarpa }\end{array}$ & $\begin{array}{l}\text { Ekstrak metanol } \\
\text { - Flavonoid } 15,62 \mathrm{mg} / \mathrm{ml} \\
\text { - Flavanol } 14,75 \mathrm{mg} / \mathrm{ml} \\
\text { - Fenolik } 16,54 \mathrm{mg} / \mathrm{ml} \\
\text { - Antioksidan } 9,12 \mathrm{mg} / \mathrm{ml}\end{array}$ & $\begin{array}{l}\text { - Antibakteri } \\
\text { - Antioksidan }\end{array}$ & Lay et al., 2014 \\
\hline 13 & $\begin{array}{l}\text { Daun } \\
\text { pepaya }\end{array}$ & $\begin{array}{l}\text { Carica papaya } \\
\text { L. }\end{array}$ & $\begin{array}{l}\text { Ekstrak } \\
\text { - Antioksidan 67,3-78,4\% }\end{array}$ & $\begin{array}{l}\text { - Antibakteri } \\
\text { - Antioksidan }\end{array}$ & $\begin{array}{l}\text { Nisa et al., } 2019 \\
\text { Zusfahair dkk., }\end{array}$ \\
\hline
\end{tabular}




\begin{tabular}{|c|c|c|c|c|c|}
\hline No & Nama lokal & Nama ilmiah & Kandungan bioaktif & Manfaat & Sumber \\
\hline & & & $\begin{array}{l}\text { - Flavonoid 36,93-76,69 } \mu \mathrm{g} / \mathrm{g} \\
\text { - Aktivitas enzim papain } \\
\text { 394,0-415,9 U/ml }\end{array}$ & & 2014 \\
\hline 14 & Daun salam & $\begin{array}{l}\text { Syzygium } \\
\text { polyanthum } \\
\text { Walp. }\end{array}$ & $\begin{array}{l}\text { Ekstrak dengan air } \\
\text { - Minyak atsiri 0,2\% } \\
\text { - Antioksidan 16,39 mg/g } \\
\text { - Flavonoid 2,78 mg/100g } \\
\text { - Fenol 40,94 mg/g } \\
\text { - Tanin 7,62 \% } \\
\text { - Saponin } 95,27 \%\end{array}$ & $\begin{array}{l}\text { - Antibakteri } \\
\text { - Antioksidan }\end{array}$ & $\begin{array}{l}\text { Harismah \& } \\
\text { Chusniatun, } \\
2017 \\
\text { Sukmasari et al., } \\
2018 \\
\text { Hermana et al., } \\
2008\end{array}$ \\
\hline 15 & $\begin{array}{l}\text { Daun } \\
\text { sambiloto }\end{array}$ & $\begin{array}{l}\text { Andrographis } \\
\text { panicula Nee }\end{array}$ & $\begin{array}{l}\text { Ekstrak dengan air } \\
\text { - Antioksidan } 23,30 \% \\
\text { - Flavonoid } 0,43 \mathrm{mg} / \mathrm{g} \\
\text { - Fenol } 184,48 \mathrm{mg} / \mathrm{g}\end{array}$ & $\begin{array}{l}\text { - Antibakteri } \\
\text { - Antioksidan }\end{array}$ & Sani et al., 2015 \\
\hline 16 & $\begin{array}{l}\text { Daun sirih } \\
\text { hijau }\end{array}$ & $\begin{array}{l}\text { Piper bettle } \\
\text { linn }\end{array}$ & $\begin{array}{l}\text { Ekstrak } \\
\text { - Antioksidan 26,51 } \mu \mathrm{g} / \mathrm{ml} \\
\text { - Fenol 0,06\% } \\
\text { - Flavonoid } 1,17 \% \\
\text { - Misyak atsiri } 4,2 \%\end{array}$ & $\begin{array}{l}\text { - Antibakteri } \\
\text { - Antioksidan }\end{array}$ & $\begin{array}{l}\text { Tiara \& Farida, } \\
2013 \\
\text { Haryuni dkk., } \\
2015\end{array}$ \\
\hline 17 & Daun teh & $\begin{array}{l}\text { Camellia } \\
\text { sinensis }\end{array}$ & $\begin{array}{l}\text { Tepung } \\
\text { - Kateken } 13,76 \% \\
\text { - Flavanol 3-4\% } \\
\text { - Alkaloid 3-4\% } \\
\text { - Zat warna (klorofil) } 0,019 \% \\
\text { - Tanin 0,012\% }\end{array}$ & Antioksidan & $\begin{array}{l}\text { Towaha, } 2013 \\
\text { Fajrina dkk., } \\
2016\end{array}$ \\
\hline 18 & $\begin{array}{l}\text { Jahe dengan } \\
\text { kulit }\end{array}$ & $\begin{array}{l}\text { Zingiber } \\
\text { officinale } \\
\text { Roscoe }\end{array}$ & $\begin{array}{l}\text { Segar } \\
\text { - Flavonoid } 325,2 \mathrm{mg} / \mathrm{kg} \\
\text { - Kaempferol } 315 \mathrm{mg} / \mathrm{kg} \\
\text { - Luteolin 10,2 mg/kg } \\
\text { - Oleoresin 12,2\% } \\
\text { - Minyak atsiri 1,5-3,8\% }\end{array}$ & $\begin{array}{l}\text { - Antioksidan, } \\
\text { - Antiinflammasi } \\
\text { - Analgesik } \\
\text { - Antikarsinogenik }\end{array}$ & $\begin{array}{l}\text { Cao et al., } 2010 \\
\text { Febriani et al., } \\
2018\end{array}$ \\
\hline 19 & Jeruk nipis & $\begin{array}{l}\text { Citrus } \\
\text { Aurantifolia }\end{array}$ & $\begin{array}{l}\text { Segar } \\
\text { - Asam sitrat 6,15\% } \\
\text { - Asam malat 0,52\% } \\
\text { - Asam laktat } 0,09 \%\end{array}$ & $\begin{array}{l}\text { - Menjaga pH } \\
\text { saluran pencernaan } \\
\text { - Menekan bakteri } \\
\text { patogen }\end{array}$ & $\begin{array}{l}\text { Setyawan et al., } \\
2019\end{array}$ \\
\hline 20 & $\begin{array}{l}\text { Kulit } \\
\text { manggis }\end{array}$ & $\begin{array}{l}\text { Garcinia } \\
\text { mangostana L. }\end{array}$ & $\begin{array}{l}\text { Ekstrak } \\
\text { - Antioksidan 64,3 } \mu \mathrm{g} / \mathrm{ml} \\
\text { - Fenol 263,3 GAE/g }\end{array}$ & Antioksidan & Fitria dkk., 2014 \\
\hline 21 & Kunyit & $\begin{array}{l}\text { Curcuma } \\
\text { domestica }\end{array}$ & $\begin{array}{l}\text { Segar } \\
\text { - Kurkumoid } 10 \% \\
\text { - Bisdesmetoksikurkumin 1- } \\
5 \% \\
\text { - Minyak atsiri (keton } \\
\text { sesquiterpen, turmeron, } \\
\text { tumeon) } 60 \% \\
\text { - Zingiberen } 25 \% \\
\text { - Vit C } 45-55 \% \\
\text { Ekstrak } \\
\text { - Gingerols } 40,3 \mathrm{~g} / \mathrm{Kg} \\
\end{array}$ & $\begin{array}{l}\text {-Antibakteri } \\
\text {-Antibiotik }\end{array}$ & $\begin{array}{l}\text { Kusbiantoro, } \\
\text { dan } \\
\text { Purwaningrum, } \\
2018 \\
\text { Wen et al., } 2019\end{array}$ \\
\hline 22 & Temulawak & $\begin{array}{l}\text { Curcuma } \\
\text { xanthorrhiza } \\
\text { Roxb }\end{array}$ & $\begin{array}{l}\text { Tepung } \\
\text { - Kurkumin 1,41-2,29\% } \\
\text { - Minyak atsiri 3,81\% } \\
\text { - Vit E 1,64\% }\end{array}$ & $\begin{array}{l}\text { - Antioksidan } \\
\text { - Antibakteri }\end{array}$ & $\begin{array}{l}\text { Khamidah dkk., } \\
2017\end{array}$ \\
\hline 23 & $\begin{array}{l}\text { Lidah } \\
\text { buaya }\end{array}$ & $\begin{array}{l}\text { Aloe vera } \\
\text { barbadensis }\end{array}$ & $\begin{array}{l}\text { Gel } \\
\text { - Flavonoid 9,17 mg/g } \\
\text { - Fenol 7,99 mg/g }\end{array}$ & $\begin{array}{l}\text { - Antioksidan } \\
\text { - Antibakteri } \\
\text { - Antijamur }\end{array}$ & $\begin{array}{l}\text { Vidic et al., } \\
2014\end{array}$ \\
\hline
\end{tabular}

822 BRILIANT: Jurnal Riset dan Konseptual Volume 5 Nomor 4, November 2020 


\begin{tabular}{|c|c|c|c|c|c|}
\hline No & Nama lokal & Nama ilmiah & Kandungan bioaktif & Manfaat & Sumber \\
\hline & & & - Antioksidan 45,6 mg/ml & $\begin{array}{l}\text { - Antiinflammasi } \\
\text { - Antitumor } \\
\text { - Analgesik } \\
\end{array}$ & \\
\hline 24 & $\begin{array}{l}\text { Buah naga } \\
\text { merah }\end{array}$ & $\begin{array}{l}\text { Hylocereus } \\
\text { polyrhizus }\end{array}$ & \begin{tabular}{ll}
\multicolumn{1}{l}{ Tepung kulit } \\
- & Fenol $31,12 \mathrm{mg} / 100 \mathrm{~g}$ \\
- & Antioksidan $51,35 \%$ \\
- & Antosianin segar $0,56 \mathrm{ppm}$ \\
- & Antosianin tepung 1,27 \\
& ppm \\
\end{tabular} & $\begin{array}{l}\text {-Antioksidan } \\
\text {-Antimikrobial } \\
\text {-Zat warna }\end{array}$ & $\begin{array}{l}\text { Manihuruk et } \\
\text { al., } 2017 \\
\text { Daniel dkk., } \\
2014\end{array}$ \\
\hline 25 & Kenikir & $\begin{array}{l}\text { Cosmos } \\
\text { caudatus }\end{array}$ & $\begin{array}{l}\text { Ekstrak } \\
\text { - Flavonoid 4,33 } \mu \mathrm{g} / \mathrm{ml} \\
\text { - Antioksidan 52,81 } \mu \mathrm{g} / \mathrm{mL}\end{array}$ & $\begin{array}{l}\text { - Antioksidan } \\
\text { - Antimikrobial }\end{array}$ & $\begin{array}{l}\text { Wahyuni et al. } \\
2018\end{array}$ \\
\hline
\end{tabular}

Berdasarkan Tabel 1 kandungan bioaktif paling banyak yang terdapat pada tanaman lokal adalah flavonoid, fenol dan antioksidan. Flavonoid merupakan salah satu metabolit sekunder pada tanaman yang mempunyai sifat antibakteri, antioksidan dan antiinflamasi (Alfaridz \& Amalia, 2018). Lebih lanjut Edi (2018) menyatakan bahwa flavonoid merupakan senyawa fenol yang tergolong dalam senyawa fitokimia yang menjadi substansi antimikroba efektif melawan berbagai macam mikroba patogen. Narita (2015) menambahkan bahwa flavonoid mampu menghambat pembentukan micelle usus tempat terjadinya penyerapan asam empedu yang salah satu fungsinya untuk melarutkan lemak melalui saluran empedu ke dalam usus, sehingga dapat meningkatkan penyerapan nutrien pakan.

Antioksidan alami yang terkandung pada tanaman lokal yaitu senyawa polifenol, karotenoid, antosianin dan vitamin. Antioksidan ini memiliki berbagai efek farmakologis seperti antiinflamasi dan antikanker (Zuraida et al., 2017). Antosianin adalah kelompok pigmen alami pada tumbuhan yang menyebabkan warna kemerah merahan, ungu hingga merah gelap letaknya di dalam cairan sel yang bersifat larut dalam air dan mempunyai sifat antioksidan (Ingrath et al., 2015). Kandungan antosianin ini dapat mempengaruhi karakteristik warna dari produk unggas. Hasil penelitian Ahmadi (2015) melaporkan skor warna kuning telur meningkat seiring dengan peningkatan level penambahan tepung daun jati yang mengandung antosianin.

Kandungan bioaktif utama pada tanaman rimpang seperti kunyit, jahe dan temulawak adalah minyak atsiri (Tabel 1). Minyak atsiri merupakan metabolit sekunder dari tanaman rimpang, mudah terbang dan mempunyai efek antibakteri (Pujianti dkk., 2013). Kunyit dan jahe dapat digunakan sebagai antibiotik alami karena mempunyai kemampuan dalam menekan mikroba patogen, memberikan kekebalan dan daya tahan tubuh, memperbaiki penampilan produksi dan sebagai appetizer (Natsir dkk., 2016).

Kandungan asam organik seperti sitrat, malat dan laktat banyak terdapat pada buah jeruk nipis dan blimbing wuluh yang berasa asam (Setyawan et al., 2019). Kandungan asam organik ini dapat dimanfaatkan sebagai acidifier alami. Acidifier merupakan asam organik yang ditambahkan ke dalam pakan atau air minum dengan tujuan untuk meningkatkan kecernaan melalui kontrol metabolisme dalam tubuh dengan cara peningkatan kinerja enzim pencernaan, menurunkan $\mathrm{pH}$ dalam usus serta menjaga keseimbangan mikrobia dalam saluran pencernaan (Pratama, 2017).

\section{Aplikasi dan Dampak}

Pemanfaatan tanaman lokal untuk diaplikasikan pada ternak unggas dapat dijadikan sebagai imbuhan pakan maupun bahan pakan alternatif. Level penggunaan 
dan aplikasi tanaman lokal pada formulasi pakan unggas serta respon terhadap produktifitas disajikan pada Tabel 2. Pada Tabel 2 terlihat tanaman lokal yang digunakan sebagai imbuhan pakan, penggunaannya rata-rata tidak lebih dari 3\% dalam formulasi pakan dan yang dimanfaatkan adalah kandungan bioaktifnya. Tamanan lokal yang digunakan pada formulasi unggas lebih dari 3\% dapat dijadikan bahan baku alternatif sekaligus dimanfaatkan kandungan bioaktifnya.

Tabel 2. Level, cara aplikasi dan respon penggunaan tanaman lokal pada formulasi pakan unggas.

\begin{tabular}{|c|c|c|c|c|c|}
\hline No & $\begin{array}{c}\text { Tanaman } \\
\text { Lokal }\end{array}$ & $\begin{array}{c}\text { Level } \\
(\%)\end{array}$ & Aplikasi & Respon & Sumber \\
\hline \multirow[t]{4}{*}{1} & $\begin{array}{l}\text { Bawang } \\
\text { putih }\end{array}$ & 0,25 & $\begin{array}{l}\text { Tepung bawang pada } \\
\text { pakan }\end{array}$ & $\begin{array}{l}\text { Meningkatkan konversi pakan dan } \\
\text { indeks prestasi ayam pedaging }\end{array}$ & $\begin{array}{l}\text { Dharmawati } \\
\text { dkk., } 2013\end{array}$ \\
\hline & & $1-1,5$ & $\begin{array}{l}\text { Tepung kulit dan } \\
\text { bawang ditambahkan } \\
\text { pada pakan }\end{array}$ & $\begin{array}{l}\text { Memperbaiki performa produksi } \\
\text { ayam petelur (HDP, egg mass, } \\
\text { konversi pakan, konsumsi) tetapi } \\
\text { belum dapat menggantikan antibiotik } \\
\text { virginamycin } \\
\begin{array}{l}\text { Meningkatkan IOFC dari } 328 \\
\text { menjadi } 441 \mathrm{Rp} / \text { butir. }\end{array}\end{array}$ & Deko, 2018 \\
\hline & & 5 & $\begin{array}{l}\text { Ekstrak ditambahkan } \\
\text { pada air minum }\end{array}$ & $\begin{array}{l}\text { Meningkatkan performa ayam } \\
\text { pedaging }\end{array}$ & $\begin{array}{l}\text { Trisna dkk., } \\
2014\end{array}$ \\
\hline & & 6 & $\begin{array}{ll}\text { Tepung } & \text { kulit } \\
\text { ditambahkan } & \text { pada } \\
\text { pakan } & \end{array}$ & $\begin{array}{l}\text { Dapat meningkatkan kecernaan } \\
\text { protein kasar dan pertambahan bobot } \\
\text { badan, namun belum dapat } \\
\text { meningkatkan persentase karkas pada } \\
\text { itik Mojosari. }\end{array}$ & $\begin{array}{l}\text { Avian Saputra } \\
\text { et al., } 2016\end{array}$ \\
\hline 2 & $\begin{array}{l}\text { Bawang } \\
\text { merah }\end{array}$ & 3 & $\begin{array}{l}\text { Tepung kulit }+3 \% \\
\text { tepung kulit bawang } \\
\text { putih }\end{array}$ & $\begin{array}{l}\text { Dapat meningkatkan kecernaan } \\
\text { protein kasar dan pertambahan berat } \\
\text { badan itik mojosari tetapi belum } \\
\text { dapat meningkatkan persentase } \\
\text { karkas. }\end{array}$ & $\begin{array}{l}\text { Saputra dkk., } \\
2016\end{array}$ \\
\hline \multirow[t]{2}{*}{3} & $\begin{array}{l}\text { Biji } \\
\text { ketumbar }\end{array}$ & $2-3$ & $\begin{array}{l}\text { Tepung ditambahkan } \\
\text { pada pakan }\end{array}$ & $\begin{array}{l}\text { Meningkatkan kinerja dan } \\
\text { kesehatan ayam petelur } \\
\text { berpotensi untuk antioksidan. }\end{array}$ & $\begin{array}{l}\text { Habiyah, } \\
2015\end{array}$ \\
\hline & & 3 & $\begin{array}{l}\text { Tepung ditambahkan } \\
\text { pada pakan }\end{array}$ & $\begin{array}{l}\text { Meningkatkan performan ayam } \\
\text { pedaging, mengurangi stres karena } \\
\text { cekaman panas. Meningkatkan IOFC } \\
\text { dari } 716 \text { menjadi } 1928 \text { Rp/ekor }\end{array}$ & $\begin{array}{l}\text { Wulandaputri, } \\
2012\end{array}$ \\
\hline \multirow[t]{2}{*}{4} & $\begin{array}{l}\text { Blimbing } \\
\text { wuluh }\end{array}$ & 0,5 & $\begin{array}{lr}\text { Dibuat } & \text { jus } \\
\text { dipisahkan } & \text { ampas } \\
\text { dan } & \text { sari, } \\
\text { ditambahkan } & \text { dalam } \\
\text { pakan } & \\
\end{array}$ & $\begin{array}{l}\text { Meningkatkan IOFC pada } \\
\text { buras dari } 8003 \text { menjadi } 9214 \\
\text { Rp/ekor }\end{array}$ & $\begin{array}{l}\text { Wiradimadja } \\
\text { dkk., } 2015\end{array}$ \\
\hline & & 3 & $\begin{array}{lr}\text { Dibuat } & \text { jus } \\
\text { dipisahkan } & \text { ampas } \\
\text { dan } & \text { sari, } \\
\text { ditambahkan } & \text { dalam } \\
\text { pakan } & \end{array}$ & $\begin{array}{l}\text { Meningkatkan konsumsi pakan dan } \\
\text { produksi pada ayam petelur serta } \\
\text { IOFC dari } 208 \text { menjadi } 288 \mathrm{Rp} / \text { butir. } \\
\text { Mampu meningkatkan kualitas } \\
\text { eksternal telur (berat telur, berat } \\
\text { kerabang, ketebalan kerabang dan } \\
\text { indeks bentuk telur). }\end{array}$ & $\begin{array}{l}\text { Prahardi dkk., } \\
2018\end{array}$ \\
\hline \multirow[t]{2}{*}{5} & $\begin{array}{l}\text { Buah } \\
\text { mengkudu }\end{array}$ & $0,4-0,6$ & Tepung dalam pakan & Meningkatkan performa ayam sentul & $\begin{array}{l}\text { Fauzan dkk., } \\
2016\end{array}$ \\
\hline & & 0,5 & $\begin{array}{l}\text { Ampas mengkudu } \\
\text { ditambahkan pada } \\
\text { pakan }\end{array}$ & $\begin{array}{l}\text { Meningkatkan efisiensi penggunaan } \\
\text { pakan setara dengan antibiotik (Zink } \\
\text { basitrasin) dalam aspek produksi dan }\end{array}$ & $\begin{array}{l}\text { Bintang dkk., } \\
2008\end{array}$ \\
\hline
\end{tabular}




\begin{tabular}{|c|c|c|c|c|c|}
\hline No & $\begin{array}{l}\text { Tanaman } \\
\text { Lokal }\end{array}$ & $\begin{array}{l}\text { Level } \\
(\%)\end{array}$ & Aplikasi & Respon & Sumber \\
\hline & & & & bobot telur ayam petelur. & \\
\hline & & $1-3$ & $\begin{array}{l}\text { Sari mengkudu } \\
\text { dalam air minum }\end{array}$ & $\begin{array}{l}\text { Menurunkan kadar lemak abdominal, } \\
\text { memperbaiki kualitas karkas, } \\
\text { mengurangi cekaman stres. }\end{array}$ & Bijanti, 2008 \\
\hline & & 2 & Tepung dalam pakan & Meningkatkan performan itik hibrida. & $\begin{array}{l}\text { Widianto } \\
\text { dkk., } 2015\end{array}$ \\
\hline & & 5 & Tepung dalam pakan & $\begin{array}{l}\text { Dapat digunakan bahan pakan ayam } \\
\text { pedaging }\end{array}$ & $\begin{array}{l}\text { Nurhayati } \\
\text { dkk., } 2005\end{array}$ \\
\hline \multirow[t]{3}{*}{6} & Buah tomat & $0,5-1$ & $\begin{array}{l}\text { Tepung ditambahkan } \\
\text { pada pakan }\end{array}$ & $\begin{array}{l}\text { Dapat meningkatkan produksi, } \\
\text { kandungan karatonoid dan Vit A serta } \\
\text { mengurangi lemak pada kuning telur } \\
\text { ayam peteur. }\end{array}$ & $\begin{array}{l}\text { Akdemir et } \\
\text { al., } 2012\end{array}$ \\
\hline & & 8 & $\begin{array}{l}\text { Bubur kering } \\
\text { ditambahkan pada } \\
\text { pakan }\end{array}$ & $\begin{array}{l}\text { Memberikan pengaruh terhadap } \\
\text { indeks kuning telur, haugh unit, dan } \\
\text { warna kuning telur ayam petelur. }\end{array}$ & $\begin{array}{l}\text { Timbuleng } \\
\text { dkk., } 2015\end{array}$ \\
\hline & & 10 & $\begin{array}{l}\text { Tepung tomat dalam } \\
\text { pakan }\end{array}$ & $\begin{array}{l}\text { Dapat digunakan bahan pakan ayam } \\
\text { petelur }\end{array}$ & $\begin{array}{l}\text { Jafari et al., } \\
2006\end{array}$ \\
\hline 7 & Daun afrika & $0,1-0,3$ & $\begin{array}{l}\text { Ditambahkan pada } \\
\text { air minum }\end{array}$ & $\begin{array}{l}\text { Meningkatkan konsumsi pakan, } \\
\text { pertambahan berat badan, konsumsi } \\
\text { air minum tetapi tidak meningkatkan } \\
\text { konversi pakan pada ayam pedaging. }\end{array}$ & $\begin{array}{l}\text { Damayanti, } \\
2019\end{array}$ \\
\hline 8 & Daun jarak & 16 & $\begin{array}{l}\text { Pencekokan (ekstrak } \\
\text { dengan air dengan } \\
\text { perbandingan } 1: 7)\end{array}$ & $\begin{array}{l}\text { Mengurangi cacing Ascaridia galli } \\
\text { sehingga menghasilkan pertambahan } \\
\text { berat badan dan konversi pakan sama } \\
\text { dengan penggunaan obat cacing } \\
\text { komersial pada ayam buras }\end{array}$ & $\begin{array}{l}\text { Suharti et al., } \\
2010\end{array}$ \\
\hline \multirow[t]{4}{*}{9} & Daun jati & 0,8 & $\begin{array}{lr}\text { Ekstrak } & \text { dengan } \\
\text { etanol } & 70 \% \\
\text { ditambahkan } & \text { dalam } \\
\text { pakan } & \end{array}$ & $\begin{array}{l}\text { Menghasilkan performa ayam petelur } \\
\text { (konsumsi, produksi, berat telur, egg } \\
\text { mass dan FCR sama dengan } \\
\text { penambahan antibiotik virginamicin } \\
0,015 \% \text { ). Meningkatkan IOFC dari } \\
303 \text { menjadi } 350 \mathrm{Rp} / \text { butir. }\end{array}$ & Edi, 2018 \\
\hline & & 1,2 & $\begin{array}{lr}\text { Ekstrak } & \text { dengan } \\
\text { etanol } & 70 \% \\
\text { ditambahkan } & \text { dalam } \\
\text { pakan } & \end{array}$ & $\begin{array}{l}\text { Menghasilkan kualitas telur ayam } \\
\text { petelur (berat telur, berat albumin, } \\
\text { berat, tebal \& persentase cangkang, } \\
\text { haugh unit, warna kuning telu sama } \\
\text { dengan penambahan antibiotik } \\
\text { virginamicin } 0,015 \% \text { ). }\end{array}$ & $\begin{array}{l}\text { Edi et al., } \\
2018\end{array}$ \\
\hline & & 6 & $\begin{array}{l}\text { Tepung ditambahkan } \\
\text { pada pakan }\end{array}$ & $\begin{array}{l}\text { Meningkatkan kualitas telur burung } \\
\text { puyuh (berat telur, putih, kuning, } \\
\text { cangkang dan nilai haugh unit) }\end{array}$ & Fa`izah, 2014 \\
\hline & & 9 & $\begin{array}{l}\text { Ekstrak ditambahkan } \\
\text { pada pakan }\end{array}$ & $\begin{array}{l}\text { Menurunkan populasi total koloni } \\
\text { bakteri patogen pada saluran } \\
\text { pencernaan burung puyuh }\end{array}$ & Ahmadi, 2015 \\
\hline \multirow[t]{3}{*}{10} & Daun katuk & $0,9-4,5$ & $\begin{array}{l}\text { Ekstrak ditambahkan } \\
\text { pada pakan }\end{array}$ & $\begin{array}{l}\text { Memperbaiki kualitas telur, } \\
\text { komposisi kimia (menurunkan } \\
\text { kolesterol, meningkatkan Vit A, } \beta \text { - } \\
\text { karoten, memodifikasi komposisi } \\
\text { asam lemak dan } \\
\text { asam amino) telur ayam petelur }\end{array}$ & $\begin{array}{l}\text { Santoso \& } \\
\text { Fenita, } 2016\end{array}$ \\
\hline & & 2,5 & $\begin{array}{l}\text { Tepung ditambahkan } \\
\text { pada pakan }\end{array}$ & $\begin{array}{l}\text { Meningkatkan produksi telur dan } \\
\text { menurunkan konversi pakan pada itik } \\
\text { mojosari }\end{array}$ & $\begin{array}{l}\text { Ekstander et } \\
\text { al., } 2013\end{array}$ \\
\hline & & $5-7,5$ & $\begin{array}{l}\text { Tepung ditambahkan } \\
\text { pada pakan }\end{array}$ & $\begin{array}{lrrr}\text { Meningkatkan warna kuning telur, } & \text { kningatkan } \\
\text { meningka } & \text { telur } & \text { dan }\end{array}$ & $\begin{array}{l}\text { Simanjuntak } \\
\text { et al., } 2013\end{array}$ \\
\hline
\end{tabular}




\begin{tabular}{|c|c|c|c|c|c|}
\hline No & $\begin{array}{l}\text { Tanaman } \\
\text { Lokal }\end{array}$ & $\begin{array}{l}\text { Level } \\
(\%)\end{array}$ & Aplikasi & Respon & Sumber \\
\hline & & & & $\begin{array}{l}\text { mengurangi bau amis pada telur itik } \\
\text { mojosari }\end{array}$ & \\
\hline & & 9 & $\begin{array}{l}\text { Tepung ditambahkan } \\
\text { pada pakan }\end{array}$ & $\begin{array}{l}\text { Meningkatkan berat badan ayam } \\
\text { pedaging }\end{array}$ & $\begin{array}{l}\text { Nasution } \\
\text { dkk., } 2014\end{array}$ \\
\hline & & 10 & $\begin{array}{l}\text { Tepung daun }+1 \% \\
\text { probiotik } \\
\text { ditambahkan pada } \\
\text { pakan }\end{array}$ & $\begin{array}{l}\text { Meningkatkan kualitas karkas itik } \\
\text { bali }\end{array}$ & $\begin{array}{l}\text { Yadnya dkk., } \\
2014\end{array}$ \\
\hline & & 15 & Tepung daun katuk & $\begin{array}{l}\text { Meningkatkan produksi dan warna } \\
\text { kuning telur pada ayam petelur }\end{array}$ & Saragih, 2016 \\
\hline \multirow[t]{2}{*}{11} & Daun kelor & 2 & $\begin{array}{l}\text { Tepung ditambahkan } \\
\text { pada pakan }\end{array}$ & $\begin{array}{l}\text { Meningkatkan konsumsi, berat telur, } \\
\text { menurunkan konversi pakan dan nilai } \\
\text { kolesterol kuning telur pada ayam } \\
\text { petelur. Meningkatkan IOFC dari } 449 \\
\text { menjadi } 456 \mathrm{Rp} / \text { butir }\end{array}$ & $\begin{array}{l}\text { Satria et al., } \\
2016\end{array}$ \\
\hline & & 5 & $\begin{array}{l}\text { Ekstrak ditambahkan } \\
\text { pada air minum }\end{array}$ & $\begin{array}{l}\text { Meningkatkan performa ayam } \\
\text { pedaging umur } 2-6 \text { minggu }\end{array}$ & $\begin{array}{l}\text { Trisna dkk., } \\
2014\end{array}$ \\
\hline 12 & $\begin{array}{l}\text { Daun } \\
\text { mahkota } \\
\text { dewa }\end{array}$ & $\begin{array}{c}0,05- \\
0,1\end{array}$ & $\begin{array}{l}\text { Tepung ditambahkan } \\
\text { pada pakan }\end{array}$ & $\begin{array}{l}\text { Menghasilkan performa ayam } \\
\text { pedaging sama dengan penambahan } \\
\text { antibiotik tetrasiklin } 50 \mathrm{ppm}\end{array}$ & $\begin{array}{l}\text { Kusumasari } \\
\text { dkk., } 2012\end{array}$ \\
\hline \multirow[t]{6}{*}{13} & $\begin{array}{l}\text { Daun } \\
\text { pepaya }\end{array}$ & 0,9 & $\begin{array}{l}\text { Jus dengan air } \\
\text { diambil sarinya } \\
\text { ditambahkan pada air } \\
\text { minum }\end{array}$ & $\begin{array}{l}\text { Meningkatkan konsumsi dan } \\
\text { pertambahan berat badan ayam arab } \\
\text { jantan stater }\end{array}$ & $\begin{array}{l}\text { Karyono } \\
\text { al., } 2019\end{array}$ \\
\hline & & 2 & $\begin{array}{l}\text { Tepung ditambahkan } \\
\text { pada pakan }\end{array}$ & 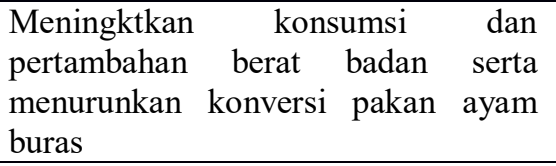 & $\begin{array}{l}\text { Hamzah, } \\
2019\end{array}$ \\
\hline & & $2-6$ & $\begin{array}{l}\text { Tepung ditambahkan } \\
\text { pada pakan }\end{array}$ & $\begin{array}{l}\text { Meningkatkan offal internal itik bali } \\
\text { yaitu kerongkongan, proventrikulus, } \\
\text { ventrikulus, hati dan empedu. }\end{array}$ & $\begin{array}{l}\text { Nugroho } \\
\text { dkk., } 2014\end{array}$ \\
\hline & & 6 & $\begin{array}{l}\text { Tepung ditambahkan } \\
\text { pada pakan }\end{array}$ & $\begin{array}{l}\text { Menurunkan konsumsi dan konversi } \\
\text { ransum tanpa menurunkan produksi } \\
\text { telur dan berat telur burung puyuh. }\end{array}$ & $\begin{array}{l}\text { Yunita dkk., } \\
2014\end{array}$ \\
\hline & & 8 & $\begin{array}{l}\text { Tepung atau jus } \\
\text { dalam pakan }\end{array}$ & $\begin{array}{l}\text { Bahan pakan, meningkatkan warna } \\
\text { kuning telur ayam arab. Pada bentuk } \\
\text { tepung dapat meningkatkan IOFC } \\
\text { dari } 1952 \text { menjadi } 2418 \text { rupiah. }\end{array}$ & $\begin{array}{l}\text { Muharlien \& } \\
\text { Nurgiartining } \\
\text { sih, } 2015\end{array}$ \\
\hline & & 10 & $\begin{array}{l}\text { Tepung daun }+1 \% \\
\text { probiotik } \\
\text { ditambahkan pada } \\
\text { pakan }\end{array}$ & $\begin{array}{l}\text { Meningkatkan kualitas karkas itik } \\
\text { bali }\end{array}$ & $\begin{array}{l}\text { Yadnya dkk., } \\
2014\end{array}$ \\
\hline \multirow[t]{3}{*}{14} & Daun salam & 1 & Tepung dalam pakan & $\begin{array}{l}\text { Meningkatkan warna kemerahan dan } \\
\text { keempukan daging ayam pedaging. }\end{array}$ & Ningsih, 2015 \\
\hline & & 3 & Tepung dalam pakan & $\begin{array}{l}\text { Menekan jumlah koloni bakteri } \\
\text { Escherichia coli dalam ekskreta ayam } \\
\text { pedaging }\end{array}$ & $\begin{array}{l}\text { Hermana et } \\
\text { al., } 2008\end{array}$ \\
\hline & & 10 & $\begin{array}{l}\text { Tepung daun }+1 \% \\
\text { probiotik } \\
\text { ditambahkan pada } \\
\text { pakan }\end{array}$ & $\begin{array}{l}\text { Meningkatkan kualitas karkas itik } \\
\text { bali }\end{array}$ & $\begin{array}{l}\text { Yadnya dkk., } \\
2014\end{array}$ \\
\hline 15 & $\begin{array}{l}\text { Daun } \\
\text { sambiloto }\end{array}$ & 0,3 & $\begin{array}{l}\text { Ekstrak ditambahkan } \\
\text { pada pakan }\end{array}$ & $\begin{array}{l}\text { Dapat menggantikan antibiotik } \\
\text { tetracyclin pada ayam pedaging. }\end{array}$ & $\begin{array}{l}\text { Ulfah dan } \\
\text { Natsir, } 2008\end{array}$ \\
\hline & & & & Meningkatkan IOFC ayam pedaging & \\
\hline
\end{tabular}




\begin{tabular}{|c|c|c|c|c|c|}
\hline No & $\begin{array}{c}\text { Tanaman } \\
\text { Lokal }\end{array}$ & $\begin{array}{c}\text { Level } \\
(\%)\end{array}$ & Aplikasi & Respon & Sumber \\
\hline & & 0,4 & $\begin{array}{l}\text { Ekstrak ditambahkan } \\
\text { pada pakan }\end{array}$ & dari 8382 menjadi 8582 Rp/ekor. & \\
\hline & & 0,4 & $\begin{array}{l}\text { Tepung ditambahkan } \\
\text { dalam pakan }\end{array}$ & $\begin{array}{l}\text { Pada itik mojosari dapat } \\
\text { meningkatkan IOFC dari } 79 \text { menjadi } \\
\text { 491 Rp/ekor }\end{array}$ & $\begin{array}{l}\text { Anahamu } \\
\text { dkk., } 2018\end{array}$ \\
\hline 16 & Daun sirih & 12,5 & $\begin{array}{l}\text { Jus (imbangan daun } \\
\text { dan air } 1: 4 \text { ) dikocor } \\
\text { pada pakan per ekor }\end{array}$ & $\begin{array}{l}\text { Meningkatkan produksi, berat telur, } \\
\text { menurunkan feed conversion rasio } \\
\text { pada ayam petelur } \\
\text { Menurunkan jumlah Escherichia coli } \\
\text { pada telur dan memperpanjang lama } \\
\text { simpan telur }\end{array}$ & $\begin{array}{l}\text { Haryuni dkk., } \\
2017\end{array}$ \\
\hline \multirow[t]{2}{*}{17} & Daun teh & 1 & $\begin{array}{lr}\text { Ampas } & \text { teh } \\
\text { difermentasi dengan } \\
\mathrm{EM}_{4} \text { sebanyak } 5 \\
\mathrm{ml} / \mathrm{kg} & \end{array}$ & $\begin{array}{l}\text { Meningkatkan PBB, konversi pakan } \\
\text { dan IOFC dari } 4190 \text { menjadi } 7251 \\
\text { rupiah/ekor pada itik cihateup. }\end{array}$ & $\begin{array}{l}\text { Kusmayadi } \\
\text { dkk., } 2020\end{array}$ \\
\hline & & 2 & $\begin{array}{l}\text { Ditambahkan pada } \\
\text { pakan }\end{array}$ & $\begin{array}{l}\text { Menurunkan kadar lemak dan } \\
\text { kolesterol kuning telur ayam petelur. }\end{array}$ & $\begin{array}{l}\text { Muharlien, } \\
2010\end{array}$ \\
\hline \multirow[t]{4}{*}{18} & Jahe merah & 0,01 & $\begin{array}{l}\text { Ektrak ditambahkan } \\
\text { pada pakan }\end{array}$ & $\begin{array}{l}\text { Meningkatkan berat telur, berat putih } \\
\text { telur, haugh unit dan menurunkan } \\
\text { kandungan kolesterol kuning telur } \\
\text { pada ayam petelur }\end{array}$ & $\begin{array}{l}\text { Wen et al., } \\
2019\end{array}$ \\
\hline & & 0,25 & $\begin{array}{l}\text { Tepung jahe merah } \\
\text { pada pakan }\end{array}$ & $\begin{array}{l}\text { Meningkatkan konsumsi, produksi, } \\
\text { bobot telur dan IOFC dari } 55.074 \\
\text { menjadi } 81.324 \text { Rp/ekor/bulan pada } \\
\text { ayam kampung }\end{array}$ & $\begin{array}{l}\text { Hudiansyah } \\
\text { dkk., } 2016\end{array}$ \\
\hline & & 0,5 & $\begin{array}{l}\text { Tepung ditambahkan } \\
\text { pada pakan }\end{array}$ & $\begin{array}{l}\text { Meningkatkan produksi dan } \\
\text { menurunkan kandungan kolesterol } \\
\text { telur pada ayam petelur }\end{array}$ & $\begin{array}{l}\text { Akbarian et } \\
\text { al., } 2011\end{array}$ \\
\hline & & $1-3$ & $\begin{array}{l}\text { Tepung ditambahkan } \\
\text { pada pakan }\end{array}$ & $\begin{array}{l}\text { Berpengaruh pada laju pakan pada } \\
\text { ayam buras }\end{array}$ & $\begin{array}{l}\text { Setyanto dkk., } \\
2012\end{array}$ \\
\hline \multirow[t]{3}{*}{19} & Jeruk nipis & $0,4-1,2$ & $\begin{array}{l}\text { Perasan jeruk nipis } \\
\text { pada pakan }\end{array}$ & $\begin{array}{l}\text { Meningkatkan efisiensi penggunaan } \\
\text { protein dengan cara step down hingga } \\
1,46 \% \text { pada ayam pedaging }\end{array}$ & Jamilah, 2012 \\
\hline & & 1 & $\begin{array}{l}\text { Perasan pada air } \\
\text { minum }\end{array}$ & $\begin{array}{l}\text { Meningkatkan IOFC dari } 16.309 \\
\text { menjadi } 16.895 \text { Rp/ekor pada ayam } \\
\text { pedaging }\end{array}$ & $\begin{array}{l}\text { Setyawan } \\
\text { dkk., } 2019\end{array}$ \\
\hline & & $1-2,5$ & $\begin{array}{l}\text { Jus jeruk nipis pada } \\
\text { air minum }\end{array}$ & Meningkatkan produksi ayam petelur & $\begin{array}{l}\text { Gultepe et al., } \\
2019\end{array}$ \\
\hline \multirow[t]{3}{*}{20} & $\begin{array}{l}\text { Kulit } \\
\text { manggis }\end{array}$ & 0,06 & $\begin{array}{l}\text { Ekstrak ditambahkan } \\
\text { pada air minum }\end{array}$ & $\begin{array}{l}\text { Performan ayam pedaging optimal } \\
\text { dan menurunkan konversi pakan }\end{array}$ & Maker, 2018 \\
\hline & & 1,5 & $\begin{array}{l}\text { Tepung ditambahkan } \\
\text { pada pakan }\end{array}$ & $\begin{array}{l}\text { Meningkatkan lemak abdominal dan } \\
\text { lemak daging pada ayam pedaging }\end{array}$ & $\begin{array}{l}\text { Maharani } \\
\text { dkk., } 2017\end{array}$ \\
\hline & & 1,5 & $\begin{array}{l}\text { Tepung }+1,5 \% \\
\text { tepung kunyit }\end{array}$ & $\begin{array}{l}\text { Memperbaiki organ dalam itik } \\
\text { pedaging (hati, gizzard, limfa dan } \\
\text { panjang usus) }\end{array}$ & $\begin{array}{l}\text { Kusmayadi } \\
\text { dkk., } 2019\end{array}$ \\
\hline \multirow[t]{3}{*}{21} & Kunyit & 0,3 & Tepung dalam pakan & $\begin{array}{l}\text { Meningkatkan daya cerna protein } \\
\text { ayam pedaging }\end{array}$ & $\begin{array}{l}\text { Pujianti et al., } \\
2013\end{array}$ \\
\hline & & 0,8 & $\begin{array}{l}\text { Enkapsulasi } \\
\text { dicampur dengan } \\
\text { jahe }\end{array}$ & $\begin{array}{l}\text { Berpengaruh pada } \mathrm{pH} \text {, viskositas } \\
\text { digesta dan jumlah villi usus ayam } \\
\text { pedaging }\end{array}$ & $\begin{array}{l}\text { Natsir dkk., } \\
2016\end{array}$ \\
\hline & & 6 & Tepung dalam pakan & $\begin{array}{l}\text { Meningkatkan bobot telur, kuning } \\
\text { telur, nilai warna kuning telur pada } \\
\text { burung puyuh. }\end{array}$ & $\begin{array}{l}\text { Hilmi et al., } \\
2018\end{array}$ \\
\hline 22 & Temulawak & 3 & Tepung dalam pakan & Menurunkan stres akibat cekaman & Masti et al., \\
\hline
\end{tabular}




\begin{tabular}{|c|c|c|c|c|c|}
\hline No & $\begin{array}{l}\text { Tanaman } \\
\text { Lokal }\end{array}$ & $\begin{array}{l}\text { Level } \\
(\%)\end{array}$ & Aplikasi & Respon & Sumber \\
\hline & & & $\begin{array}{l}+40 \text { ppm mineral } \\
\text { zink pada air minum }\end{array}$ & panas pada ayam pedaging & 2020 \\
\hline & & 4 & Tepung dalam pakan & $\begin{array}{l}\text { Berpengaruh pada warna daging dan } \\
\text { tekstur pada ayam pedaging }\end{array}$ & $\begin{array}{l}\text { Yunilas dkk., } \\
2005\end{array}$ \\
\hline \multirow[t]{2}{*}{23} & Lidah buaya & 0,1 & $\begin{array}{l}\text { Gel ditambahkan } \\
\text { pada pakan }\end{array}$ & $\begin{array}{l}\text { Memperbaiki konversi pakan, } \\
\text { meningkatkan ukuran dan fungsi } \\
\text { saluran pencernaan dan penurunan } \\
\text { jumlah total bakteri aerob di dalam } \\
\text { saluran pencernaan ayam pedaging }\end{array}$ & $\begin{array}{l}\text { Sinurat et al., } \\
2003\end{array}$ \\
\hline & & 0,75 & $\begin{array}{l}\text { Gel ditambahkan } \\
\text { pada pakan }\end{array}$ & $\begin{array}{l}\text { Memperbaiki pertambahan berat } \\
\text { badan, mengurangi kadar glukosa } \\
\text { darah pada ayam pedaging }\end{array}$ & $\begin{array}{l}\text { Sulistyoningsi } \\
\text { h dkk., } 2014\end{array}$ \\
\hline \multirow[t]{2}{*}{24} & $\begin{array}{l}\text { Kulit buah } \\
\text { naga }\end{array}$ & 3 & $\begin{array}{l}\text { Tepung }+3 \% \text { tepung } \\
\text { dalam pakan }\end{array}$ & $\begin{array}{l}\text { Meningkatkan warna kuing telur dan } \\
\text { menurunkan haugh unit pada burung } \\
\text { puyuh }\end{array}$ & $\begin{array}{l}\text { Hilmi dkk., } \\
2016\end{array}$ \\
\hline & & 6 & Tepung dalam pakan & $\begin{array}{l}\text { Digunakan bahan baku pakan ayam } \\
\text { pedaging. }\end{array}$ & $\begin{array}{l}\text { Astuti dkk., } \\
2016\end{array}$ \\
\hline \multirow[t]{2}{*}{25} & $\begin{array}{l}\text { Daun } \\
\text { Kenikir }\end{array}$ & 5 & Tepung dalam pakan & $\begin{array}{l}\text { Menurunkan kadar eritrosit, } \\
\text { hemoglobin, dan hematokrit tetapi } \\
\text { tidak nyata secara statistik }\end{array}$ & $\begin{array}{l}\text { Arifin \& } \\
\text { Rinawidiastut } \\
\text { i, } 2019\end{array}$ \\
\hline & & 10 & $\begin{array}{l}\text { Tepung dalam pakan } \\
\text { komersial }\end{array}$ & $\begin{array}{l}\text { Meningkatkan produktivitas telur } \\
\text { burung puyuh (produksi, konversi } \\
\text { dan efisiensi pakan). }\end{array}$ & $\begin{array}{l}\text { Ngatman } \\
\text { dkk., } 2018\end{array}$ \\
\hline
\end{tabular}

Keterangan : HDP (Hen Day Production), FCR (Feed Conversion Ratio), PBB (Pertambahan Bobot Badan), IOFC (Income Over Feed Cost).

Penggunaan tanaman lokal pada formulasi unggas harus sesuai dengan level penggunaan dan cara aplikasi yang tepat. Pasaribu (2019) menjelaskan tanaman lokal banyak mengandung bioaktif seperti obat sehingga penggunaannya harus tepat. Penggunaan tersebut dibatasi oleh kandungan antinutrisi misalnya tanin dan saponin (Tabel 1). Antinutrisi adalah zat yang dapat mengganggu pemanfaatan pakan dan mempengaruhi kesehatan serta produksi hewan melalui mekanisme penurunan asupan nutrisi, gangguan pencernaan dan penyerapan serta mengakibatkan efek samping merugikan lainnya (Yanuartono dkk., 2017). Hal tersebut akan berbeda bila diberikan pada level yang tepat. Menurut Mahdalena dkk. (2013) menyatakan bahwa pemberian saponin pada pakan ternak unggas seperti ayam pedaging diketahui dapat meningkatkan pertumbuhan dan efisiensi pakan, serta meningkatkan kualitas daging ternak, meningkatkan performans reproduksi ayam pejantan. Pemberian tanin ekstrak anggur dalam jumlah tinggi (3\%) pada unggas menurunkan performan ayam pedaging, tetapi pada level optimal (1\%) dapat menghambat bakteri patogen (Hughes et al., 2005). Schiavone et al. (2008) menambahkan pemberian tanin kayu chestnut $(0,20 \%)$ dapat meningkatkan pertumbuhan dan mengurangi kematian.

Penggunaan tanaman lokal sebagi bahan baku alternatif juga harus tepat karena sebagian besar tanaman mangandung serat kasar tinggi, ternak unggas mempunyai keterbatasan dalam mencerna serat kasar (Sultana et al., 2016). Lebih lanjut Has dkk., (2014) menyatakan bahwa pada level tertentu serat kasar juga dibutuhkan oleh ternak unggas untuk efek toksikologi, efek prebiotik dan efesiensi pakan sebaliknya dalam jumlah yang terlalu tinggi dapat menurunkan kecernaan pakan.

Secara umum tanaman lokal yang digunakan secara tepat (level dan cara aplikasinya) dapat meningkatkan produktifitas ternak unggas dan meningkatkan 
konsumsi karena pengaruh kandungan bioaktifnya. Bioaktif golongan polifenol mudah mengalami perubahan selama penanganan (Zulkifli et al., 2020). Menurut Natsir dkk., (2016) bioaktif yang terdapat dalam jahe dan kunyit seperti minyak atsiri, kurkumin dan oleoresin rentan hilang, berkurang atau bahkan rusak akibat penggilingan dan pemanasan. Salah satu yang mudah dilakukan untuk meminimalkan perubahan kandungan bioaktif adalah dengan memilih aplikasi dalam bentuk tepung dan dengan pengeringan yang tepat misalnya suhu diatur tidak lebih dari $50^{\circ} \mathrm{C}$ untuk mengurangi hilangnya bioaktif pada bawang putih (Deko, 2018). Pemilihan metode ekstrak dan pelarut yang tepat disesuaikan dengan kandungan bioaktif yang akan diambil. Supriningrum dkk., (2018) menyatakan bahwa suhu dan lama pengeringan akan mempengaruhi kandungan flavonoid dan kurkumin pada simplisia. Lebih lanjut Kushwah et al., (2013) menyatakan pelarut dan metode ekstraksi akan mempengaruhi kandungan bioaktif tanaman.

Pada Tabel 2 nampak bahwa aplikasi penggunaan tanaman lokal pada ternak unggas secara umum level penggunaan bentuk tepung lebih tinggi dari pada dibuat ekstrak. Hal tersebut dapat terjadi karena kandungan bioaktif ekstrak lebih tinggi dari pada tepung. Kandungan bioaktif pada bahan ekstrak terkonsentrasi pada komponen yang diinginkan saja (misal flavonoid, antosianin dan antioksidan) sehingga menurunkan atau menghilangkan komponen bioaktif lainnya. Nurjanah dkk., (2012) menjelaskan ekstraksi merupakan proses penarikan komponen bioaktif bahan dengan pelarut dengan tujuan untuk mendapatkan bagian tertentu yang diinginkan. Kelebihan bentuk tepung adalah mudah pembuatan, aplikasi lebih mudah bila dicampurkan dalam pakan dan semua kandungan bioaktif pada tanaman lokal tersebut dapat dimanfaatkan dan lebih stabil.

Tanaman lokal yang dicampurkan dalam formulasi pakan lebih dari 3\% adalah bawang putih, buah mengkudu, buah tomat, daun jati, daun katuk, daun kelor, daun pepaya, daun salam, kunyit, temulawak, buah naga dan kenikir. Kandungan makro nutrien dari tanaman lokal tersebut seperti bahan kering, protein kasar, serat kasar, lemak kasar, abu dan energi metabolis harus diperhitungkan dalam membuat formulasi pakan karena akan mengubah komposisi nutrien utama. Kandungan makro nutrien beberapa tanaman lokal disajikan pada Tabel 3.

Tabel 3. Kandungan nutrien tanaman lokal di Indonesia

\begin{tabular}{lccccccl}
\hline \multicolumn{1}{c}{ Tanaman } & BK & PK & LK & SK & Abu & EM & \multicolumn{1}{c}{ Sumber } \\
\hline Tepung bawang putih & 41,1 & 6,4 & 0,5 & 2,1 & - & 1490 & Deko, 2018 \\
Tepung buah mengkudu & 87,1 & 9,0 & 1,5 & 24,9 & - & $3155^{*}$ & Nurhayati dkk., 2005 \\
Tepung buah tomat & 90,0 & 20,7 & 7,3 & 35,0 & 4,2 & 1760 & Jafari et al., 2006 \\
Tepung kulit buah naga & 88,3 & 8,9 & 2,6 & 25,5 & 18,7 & $2301^{*}$ & Daniel dkk., 2014 \\
Tepung daun jati & 89,9 & 11,0 & 3,8 & 22,0 & 8,1 & 2190 & Ahmadi, 2015 \\
Daun katuk segar & 24,7 & 8,3 & 9,1 & - & 2,4 & 1341 & Santoso, 2018 \\
Daun katuk kering & 91,8 & 28,6 & 4,2 & 12,0 & 10,6 & 2557 & Saragih, 2016 \\
Tepung daun kelor & 95,9 & 28,4 & 2,7 & 12,6 & 7,9 & 3073 & Aminah dkk., 2015 \\
Tepung daun pepaya & 87,3 & 16,7 & 8,5 & 16,2 & 12,4 & 2953 & Muharlien dan \\
& & & & & & & Nurgiartiningsih, 2015 \\
Tepung daun salam & 86,9 & 14,2 & 10,9 & 9,4 & 12,8 & 3010 & TKPI, 2019 \\
Kunyit segar & 15,1 & 2,0 & 2,7 & 0,6 & 1,3 & 690 & TKPI, 2019 \\
Daun kenikir segar & 12,4 & 3,7 & 0,5 & 5,8 & 1,7 & 450 & TKPI, 2019 \\
\hline
\end{tabular}

Keterangan : BK (bahan kering), PK (protein kasar), LK (serat kasar), EM (energi metabolis), *EM = 0,72 GE (NRC, 1994) 
Pemanfaatan tanaman lokal yang berupa hasil samping dapat meningkatkan nilai manfaat dari bahan tersebut. Pemanfaatan tanaman lokal beberapa diantaranya dapat meningkatkan profit peternak yang dapat dilihat dengan indikator peningkatan IOFC (Income Over Feed Cost) yang merupakan selisih pendapatan dengan total biaya pakan yang dikeluarkan (Tabel 2). Menurut Hidayat (2012), salah satu penunjang kemandirian usaha peternakan unggas adalah dengan memanfaatkan bahan pakan lokal. Ketersediaan bahan pakan lokal akan dapat berkelanjutan karena umumnya daerah di Indonesia mempunyai ketersediaan bahan pakan yang belum termanfaatkan secara optimal (Sutanto \& Mulatmi, 2017). Saat ini baru sekitar 30-40\% dari hasil samping produk pertanian dan perkebunan yang sudah dimanfaatkan sebagai pakan (Edi, 2020). Pemanfaatan bahan pakan lokal dapat penunjang kemandirian usaha peternakan unggas dengan cara pembuatan imbuhan pakan dari tanaman lokal.

\section{KESIMPULAN}

Tanaman lokal di Indonesia dapat digunakan sebagai imbuhan pakan dan sebagian dapat digunakan sebagai bahan pakan alternatif. Tanaman lokal pada level dan cara aplikasi yang tepat dapat meningkatkan produktifitas ternak unggas. Level penggunaan bentuk tepung relatif lebih tinggi dari pada ekstrak. Kandungan bioaktif utama tanaman lokal adalah fenol, flavonoid, antosianin, minyak atsiri, asam organik. Kandungan bioaktif tersebut secara umum mempunyai sifat antibakteri, antioksidan dan antijamur dan zat warna alami. Pemanfaatan bahan pakan lokal dapat penunjang kemandirian usaha peternakan unggas dengan cara pembuatan imbuhan pakan dari tanaman lokal.

\section{SARAN}

Disarankan kepada peternak untuk memanfaatkan tanaman lokal sebagai imbuhan pakan maupun bahan pakan alternatif sesuai level yang direkomendasikan. Pemanfaatan kandungan bioaktif tanaman lokal yang ada disekitar lingkungan dapat menunjang produktifitas dan kemandirian usaha peternakan unggas.

\section{DAFTAR RUJUKAN}

Ahmadi, S. E. T. 2015. Penambahan tepung dan ekstrak daun jati (Tectona grandis Linn. f) pada puyuh Coturnix japonica. Tesis. Sekolah Pascasarjana Program Studi Nutrisi dan Pakan. Institut Pertanian Bogor

Akbarian, A., Golian, A., Sheikh Ahmadi, A., \& Moravej, H. 2011. Effects of ginger root (Zingiber officinale) on egg yolk cholesterol, antioxidant status and performance of laying hens. Journal of Applied Animal Research, 39(1), 19-21.

Akdemir, F., Orhan, C., Sahin, N., Sahin, Dr K. \& Hayirli, A. 2012. Tomato powder in laying hen diets: effects on concentrations of yolk carotenoids and lipid peroxidation. British Poultry Science, 53(5) : 675-680

Alfaridz, F., \& Amalia, R. 2018. Review jurnal : klasifikasi dan aktivitas farmakologi dari senyawa aktif flavonoid. Farmaka, 16(3) : 1-9

Anahamu, Y. M., Yulianti, D. L., \& Hadiyani, D. P. P. 2018. Pengaruh level feed additive tepung daun sambiloto (Andrographis paniculeta) terhadap nilai ekonomis pakan dan income over feed cost itik mojosari. Jurnal Sains Peternakan, 6(2), 42-49. 
Arifin, H. D., \& Rinawidiastuti. 2019. Pengaruh suplementasi tepung kenikirterhadap eritrosit, hemoglobin dan hematokritburung puyuh. Proceeding of The URECOL, 470-477.

Astuti, I., Mastika, I. M., \& Dewi, G. K. 2016. Performan broiler yang diberi ransum mengandung tepung kulit buah naga tanpa dan dengan Aspergillus Niger terfermentasi. Majalah Ilmiah Peternakan, 19(2) : 65-70

Avian Saputra, Y., Mangisah, I., \& Sukamto, B. 2016. Pengaruh penambahan tepung kulit bawang terhadap kecernaan protein kasar pakan, pertambahan bobot badan dan persentase karkas itik Mojosari. Jurnal Ilmu-Ilmu Peternakan, 26(1), 29-36.

Bijanti, R. 2008. Potensi sari buah mengkudu (Morinda Citrifolia) terhadap kualitas karkas, kadar vitamin $\mathrm{C}$ dan kadar malonedialdehide (MDA) dalam Darah Ayam Pedaging. Media Kedokteran Hewan, 24(1) : 43-48

Bintang, I. A. K., Sinurat, P., Purwadaria, T. 2008. Penambahan Antibiotika dan Bioaktif Ampas Mengkudu terhadap Produksi Telur Ayam. JITV, 13(2) : 83-88

Cao, J., Chen, W., Zhang, Y., Zhang, Y., \& Zhao, X. 2010. Content of Selected Flavonoids in 100 Edible Vegetables and Fruits. Food Science and Technology Research, 16(5) : 395-402

Cervantes, H. M. 2012. The future of antibiotic growth promoters in poultry production. Worlds Poultry Congress, XXIV.

Damayanti, P. Mihrani, Surug, M. Y. 2019. Pemanfaatan ekstrak daun afrika (Vernonia amydalina) terhadap performa broiler. Jurnal Agrisistem, 15(1) : 23-28

Daniel, R. S., Osfar, S., \& Irfan, H. D. 2014. Kajian Kandungan Zat Makanan dan Pigmen AntosianinTiga Jenis Kulit Buah Naga (Hylocereus sp.) Sebagai Bahan Pakan Ternak. Tesis. Fakultas Peternakan. Universitas Brawijaya Malang

Deko, M. K. 2018. Efek penggunaan tepung umbi dan kulit bawang putih (Allium sativum Linn) sebagai feed additive terhadap penampilan produksi, kualitas telur dan profil darah ayam petelur. Tesis. Program Magister Ilmu Ternak. Fakultas Peternakan Universitas Brawijaya.

Deko, M. K., Djunaidi, I. H., \& Natsir, M. H. 2018. Efek penggunaan tepung umbi dan kulit bawang putih (Allium sativum Linn) sebagai feed additive terhadap penampilan produksi ayam petelur. Jurnal Ilmu-Ilmu Peternakan, 28(3), 192.

Dharmawati, S., Firahmi, N., \& Parwanto, P. 2013. Penambahan Tepung Bawang Putih (Allium Sativum L) sebagai Feed Additif dalam Ransum terhadap Penampilan Ayam Pedaging. Ziraa'ah Majalah Ilmiah Pertanian, 38(3), 17-22.

Edi, D. N. 2018. Daya hambat mikroba ekstrak daun jati (Tectona grandis Linn. f) dan efek penggunaanya dalam pakan ayam petelur. Tesis. Program Magister Ilmu Ternak. Fakultas Peternakan Universitas Brawijaya.

Edi, D. N. 2020. Analysis of Regional Potency and Local Feed Resources to Develop Native Chicken in East Java Province. Jurnal Ternak, 11(2) : 7-22

Edi, D. N., Natsir, M. H., \& Djunaidi, I. 2018. Pengaruh penambahan ekstrak daun jati (Tectona grandis linn. F) dalam pakan terhadap performa ayam petelur. Jurnal Nutrisi Ternak Tropis, 1(1), 34-44.

Edi, D. N., Natsir, M. H., \& Djunaidi, I. H. 2018. The Effect of Dietary Teak Leaf Extract (Tectona grandis Linn. $f$ ) on Egg Quality of Laying Hens . Scholars Journal of Agriculture and Veterinary Sciences (SJAVS), 5(9) : 490-497

Ekstander, R., Kususiyah, K., \& Hidayat, H. 2013. Pemberian Tepung Daun Katuk (Sauropus androgynus (L.) Merr) Dalam Ransum Itik Mojosari (Anas javanica) 
Untuk Meningkatkan Produksi Telur. Jurnal Sain Peternakan Indonesia, 8(1), 5764.

Etikaningrum dan S. Iwantoro. 2017. Kajian Residu Antibiotika pada Produk Ternak Unggas di Indonesia. Jurnal Ilmu Produksi dan Teknologi Hasil Peternakan. 5(1) 29-33

Fa`izah, N. N. 2014. Penggunaan tepung daun jati (Tectona grandiss Linn. f.) dalam ransum terhadap kualitas telur puyuh (Coturnix coturnix japonica). Skripsi. Departemen Ilmu Nutrisi dan Teknologi Pakan. Fakultas Peternakan. Institut Pertanian Bogor

Fauzan, R., Tanwiriah, W., Asmara, I. Y. 2016. Pengaruh Penambahan Tepung Mengkudu Dalam Ransum Terhadap Performa Ayam Sentul. Students $e$ Journal, 5(4) : 1-10

Febriani, Y., Riasari, H., Winingsih, W., Aulifa, D. L., \& Permatasari, A. 2018. The Potential Use of Red Ginger (Zingiber officinale Roscoe) Dregs as Analgesic. Indonesian Journal of Pharmaceutical Science and Technology, 1(1), 57-64.

Fitria, S., Maharani, S., Supadmo \& Zuprizal. 2014. Pengaruh Penambahan Tepung Kulit Manggis (Garcinia Mangostana L.) sebagai Aditif Pakan terhadap Pertumbuhan dan Produksi Karkas Ayam Broiler. Buletin Peternakan, 38(2), 8389.

Gheisar, M., \& Kim, I. H. 2018. Phytobiotics in poultry and swine nutrition - a review. Italian Journal of Animal Science, 17(1), 92-99.

Graham, J. P., Boland, J. J., \& Silbergeld, E. 2007. Growth promoting antibiotics in food animal production: An economic analysis. Public Health Reports, 122(1), 79-87.

Gultepe, E. E., Iqbal, A., Cetingul, I. S., Uyarlar, C., Ozcinar, U., \& Bayram, I. 2019. Effects of Lemon Juice on Performance, Egg Quality Trait, and Some Blood Parameters of Laying Hens in the Late Phase of Production. Acta Veterinaria Eurasia, 45(2), 56-63.

Habiyah, U. 2015. Suplementasi biji ketumbar (Coriandrum sativum Linn) terhadap produktivitas, hematologi darah dan organ dalam ayam petelur. Tesis. Sekolah Pascasarjana. Institut Pertanian Bogor.

Hamzah, M. H. 2019. Pengaruh pemberian tepung daun pepaya dalam ransum pakan ayam buras terhadap bobot ayam buras. Skripsi. Program Studi Peternakan. Fakultas Peternakan. Universitas Nusantara PGRI Kediri

Harismah, K., \& Chusniatun. 2017. Pemanfaatan daun salam (Eugenia polyantha) sebagai obat herbal dan rempah penyedap makanan. Warta LPM, 19(2), 110-118.

Haryuni, H. 2014. Efek Penambahan Jus Daun Sirih (Piper bettle linn) Sebagai Aditif Pakan Terhadap Sifat Antimikroba Dan Performans Ayam Petelur. Thesis. Minat Nutrisi dan Makanan Ternak. Jurusan Ilmu Ternak. Fakultas Peternakan. Universitas Brawijaya. Malang

Haryuni, N., Widodo, E., \& Sudjarwo, E. 2015. Aktivitas antibakteri jus daun sirih (Piper bettle linn) terhadap bakteri patogen dan kualitas telur selama penyimpanan. Journal of Tropical Animal Production, 16(1), 48-54

Haryuni, N., Widodo, E., \& Sudjarwo, E. 2017. Efek Penambahan Jus Daun Sirih (Piper Bettle Linn) Sebagai Aditif Pakan Terhadap Performa Ayam Petelur. Briliant: Jurnal Riset dan Konseptual, 2(4), 429-433. 
Has, H., Napirah, A., dan Indi, A. 2014. Efek peningkatan serat kasar dengan penggunaan daun murbei dalam ransum broiler terhadap persentase bobot saluran pencernaan. JITRO, 1(1) : 63-69

Hermana, W., Puspitasari, D. I., Wiryawan, K. G., \& Suharti, S. 2008. Pemberian Tepung daun salam (Syzygium polyanthum (Wight) Walp.) dalam Ransum sebagai bahan antibakteri Escherichia coli terhadap organ dalam ayam broiler. Media Peternakan, 31(1) : 63-70

Hidayat, C. 2012. Pengembangan Produksi Ayam Lokal Berbasis Bahan Pakan Lokal. WARTAZOA, 22(2) : 85-98

Hilmi, M., Prastujati, A. U., \& Khusnah, A. 2018. Penambahan Kulit Buah Naga Merah (Hylocereus undatus) dan Kunyit (Curcuma domestica rhizomes) sebagai Pigment Feed Additive terhadap Kualitas Telur Puyuh (Cortunix cortunix japonica). Jurnal Sain Peternakan Indonesia, 13(2), 111-118.

Hudiansyah, P., Suprijatna, E., \& Sarengat, W. 2016. Pengaruh Pemberian Tepung Jahe Merah (Zingiber Officinale Var. Rubrum) Dalam Ransum Terhadap Produksi Telur Ayam Kampung Umur 27-31 Minggu. Animal Agriculture Journal, 2(3), 21-30.

Hughes, R. J., Brooker, J. D., \& Smyl, C. 2005. Growth rate of broiler chickens given condensed tannins extracted from grape seed. In Proceedings of the 17th Australian Poultry Science Symposium, Sydney, New South Wales, Australia, 7-9 February 2005 (pp. 65-68). Poultry Research Foundation.

Ingrath, W., Nugroho, W. A., \& Yulianingsih, R. 2015. Ekstraksi pigmen antosianin dari kulit buah naga merah (Hylocereus costaricensis) sebagai pewarna alami makanan dengan menggunakan microwave (kajian waktu pemanasan dengan microwave dan penambahan rasio pelarut aquades dan asam sitrat). Jurnal Bioproses Komoditas Tropis, 3(3), 1-8.

Jafari, M., Pirmohammadi, R., \& Bampidis, V. 2006. The use of dried tomato pulp in diets of laying hens. Int. J. Poult. Sci, 5(7), 618-622.

Jamilah, J. (2016). Efek penambahan jeruk nipis pada performa broiler starter yang diberi pakan stepdown. Buletin Nutrisi dan makanan Ternak 12(2) :83-88

Jumiarni, W. O., \& Komalasari, O. 2017. Eksplorasi jenis dan pemanfaatan tumbuhan obat pada masyarakat suku muna di permukiman kota wuna. Traditional Medicine Journal 22(1) : 45-56

Karyono, T., Nofrida, H., Herlina, B., \& Arifin, M. 2019. Level Ekstrak Daun Pepaya (Carica papaya L.) dalam Air Minum Terhadap Performans Ayam Arab Jantan Periode Starter. Jurnal Peternakan Indonesia, 21(3), 294-302

Khamidah, A., Antarlina, S. S., Sudaryono, T. 2017. Ragam Produk Olahan Temulawak Untuk Mendukung Keanekaragaman Pangan. Jurnal Litbang Pertanian, 36(1) : 112

Kusbiantoro, D., \& Purwaningrum, Y. 2018. Pemanfaatan kandungan metabolit sekunder pada tanaman kunyit dalam mendukung peningkatan pendapatan masyarakat. Kultivasi, 17(1) : 544-549.

Kushwah, P., Kaur, Ramandeep, S. 2013. In-Vitro antioxidant potential and phytochemical screening of Tectona grandis Linn. leaves. International Journal of Pharmaceutical and Medicinal Research, $1: 33-38$

Kusmayadi, A., Prayitno, C. H., \& Rahayu, N. 2019. persentase organ dalam itik cihateup yang diberi ransum mengandung kombinasi tepung kulit buah manggis 
(Garcinia mangostana L) dan tepung kunyit (Curcuma domestica V). Jurnal Peternakan Nusantara, 5(1), 1-12.

Kusmayadi, A., Sundari, R. S., \& Bachtiar, K. R. 2020. Suplementasi Ampas Teh Hijau Fermentasi pada Pakan terhadap Performa dan Income Over Feed Cost Itik Cihateup. Jurnal Ilmu dan Teknologi Peternakan Tropis, 7(3), 233-237.

Kusumasari, Y. F. Y., Yunianto, V. D., \& Suprijatna, E. 2012. Pemberian fitobiotik yang berasal dari mahkota dewa (phaleria macrocarpa) terhadap kadar hemoglobin dan hematokrit pada ayam broiler. Jurnal Aplikasi Teknologi Pangan, 1(4) : 129-132

Lay, M. M., Karsani, S. A., Mohajer, S., \& Abd Malek, S. N. 2014. Phytochemical constituents, nutritional values, phenolics, flavonols, flavonoids, antioxidant and cytotoxicity studies on Phaleria macrocarpa (Scheff.) Boerl fruits. BMC Complementary and Alternative Medicine, 14(1), 152.

Magdalena, S., Natadiputri, G. H., Nailufar, F., \& Purwadaria, T. 2013. Utilization of Natural Products as Functional Feed. WARTAZOA. Indonesian Bulletin of Animal and Veterinary Sciences, 23(1), 31-40.

Maharani, S., Fitria, S., Supadmo, S., \& Zuprizal, Z. 2017. Pengaruh Suplementasi Tepung Kulit Manggis (Garcinia mangostana L.) dalam Ransum terhadap Produksi Karkas dan Perlemakan Ayam Broiler. ZOO INDONESIA, 25(1) : 1-7

Maker, F. (2018). Pengaruh penambahan ekstrak kulit manggis (Garcinia mangostana L.) Dalam ransum terhadap performans produksi ayam broiler. Jurnal FAPERTANAK: Jurnal Pertanian dan Peternakan, 3(1), 48-59.

Manihuruk, F. M., Suryati, T., \& Arief, I. I. 2017. Effectiveness of the Red Dragon Fruit (Hylocereus polyrhizus) Peel Extract as the Colorant, Antioxidant, and Antimicrobial on Beef Sausage. Media Peternakan, 40(1), 47-54.

Masti, H., Nabila, S., Lammin, A., Junaidi, J., \& Nova, T. D. 2020. Penambahan Rimpang Temulawak (Curcuma xanthorriza Roxb) dan Mineral Zink dalam Pakan untuk Menilai Performans, Organ Fisiologi, dan Gambaran Darah Ayam Broiler dalam Situasi Stress Panas. Jurnal Peternakan Indonesia (Indonesian Journal of Animal Science), 22(2), 184.

Muharlien, M., \& Nurgiartiningsih, A. V. M. 2015. Pemanfaatan Limbah Daun Pepaya Dalam Bentuk Tepung dan Jus Untuk Meningkatkan Performans Produksi Ayam Arab. Research Journal of Life Science, 2(2), 93-100.

Muharlien. 2010. Meningkatkan kualitas telur melalui penambahan teh hijau dalam pakan ayam petelur. Jurnal Ilmu dan Teknologi Hasil Ternak, 5(1) : 32-27

Namuli, A., Abdullah, N., Sieo, C. C., Zuhainis, S. W., \& Oskoueian, E. 2011. Phytochemical compounds and antibacterial activity of Jatropha curcas Linn. extracts. Journal of Medicinal Plants Research, 5(16), 3982-3990

Narita E. A. R. 2015. Bay leaf in dyslipidemia therapy. Jurnal Majority, 4(4): 64-69.

Nasution, R. A. P., Atmomarsono, U., \& Sarengat, W. 2016. Pengaruh penggunaan tepung daun katuk (Sauropus androgynus) dalam ransum terhadap performa ayam broiler. Animal Agriculture Journal, 3(2), 334-340.

Natsir, M. H. Widodo, E., \& Muharlin. 2016. Penggunaan kombinasi kunyit (Curcuma domestica) dan jahe (Zingiber officinale) bentuk enkapsulasi dan tanpa enkapsulasi terhadap karakteristik usus dan mikroflora usus ayam pedaging. Buletin Peternakan, 40(1), 1-10

Ngatman, T., Arifin, H. D., \& Rinawidiastuti, R. 2019. Produktivitas Burung Puyuh Pengaruh Suplementasi Tepung Daun Kenikir dalam Pakan Komersial. Proceeding of The URECOL, 348-354. 
Ningsih, N. 2015. Pemanfaatan Tepung Daun Salam (Eugenia Polyantha Wight) Dalam Pakan Terhadap Kualitas Fisik Daging Ayam Pedaging. Tesis. Program Magister Ilmu Ternak. Fakultas Peternakan Universitas Brawijaya.

Nisa, F. Z., Astuti, M., Haryana, S. M., \& Murdiati, A. 2019. Antioxidant Activity and Total Flavonoid of Carica papaya L. Leaves with Different Varieties, Maturity and Solvent. AgriTECH, 39(1), 54.

Nugroho, E., Nuriyasa, I. M., Siti, N. W. 2014. Offal internal itik bali yang diberi ransum komersial dengan suplementasi daun pepaya (Carica Papaya,L). Jurnal Peternakan Tropika, 2(3) : 476-486

Nurhayati, N. 2008. Pengaruh Pemberian Jus Buah Mengkudu (Morinda citrifolia) dalam Air Minum Terhadap Penampilan Ayam Broiler Jantan. Jurnal Agripet, $8(1), 39-44$.

Nurhayati, Nelwida \& Marsadayanti. 2005. Pengaruh penggunaan tepung buah mengkudu dalam ransum terhadap bobot karkas ayam broiler. J. Indon. Trop. Anim. Agric, 30(2) : 96-101

Nurjanah, N., Azka, A., \& Abdullah, A. 2012. Aktivitas antioksidan dan komponen bioaktif semanggi air (Marsilea crenata). Asian Journal of Innovation and Entrepreneurship, 1(03), 152-158.

Oka, K. A. Wiyana, I. M. Sugitha dan Miwada, I. N. S. 2016. Identifikasi Sifat Fungsional dari Daun Jati, Kelor dan Kayu Manis dan Potensinya sebagai Sumber Antioksidan pada Edible Film. Jurnal-Sain-eternakan Indonesia, 11(1) : 1-8

Omede, A., Suleiman, M.S., Atanu, F.O., Sheneni, V.D., Jegede, E.R. 2018. Evaluation of antioxidant and cytotoxic properties of Vernonia Amygdalina. International Journal of Plant studies, Int J Plant Stu. 1(1): 1-6.

Pasaribu, T. 2019. Peluang zat bioaktif tanaman sebagai alternatif imbuhan pakan antibiotik pada ayam. Jurnal Litbang Pertanian Vol, 38(2), 96-104.

Prahadi, J. A., Widodo, E., dan Irfan H. Djunaidi, I. H. Pengaruh penambahan sari belimbing wuluh (Averrhoa bilimbi L.) sebagai acidifier dalam pakan terhadap penampilan produksi ayam petelur. J. Nutrisi Ternak, 1(1) : 10-18

Pratama, A. S. 2017. Penambahan air perasan jeruk nipis (Citrus aurantiifolia) terhadap berat dan panjang relatif usus halus serta konsumsi pakan ayam broiler Skripsi. Program Studi S1 Peternakan Fakultas Peternakan Dan Pertanian Universitas Diponegoro Semarang.

Prati, P., Henrique, C. M., Souza, A. S. de, Silva, V. S. N. da, \& Pacheco, M. T. B. 2014. Evaluation of allicin stability in processed garlic of different cultivars. Food Science and Technology (Campinas), 34(3), 623-628.

Pujianti, A., Jaelani, A., \& Widaningsih, N. 2013. Penambahan Tepung Kunyit (Curcuma domestica) Dalam ransum Terhadap Daya Cerna Protein dan Bahan Kering Pada Ayam Pedaging. Ziraa'ah Majalah Ilmiah Pertanian, 36(1), 49-59.

Ramiah, S. K., Zulkifli, I., Rahim, N. A. A., Ebrahimi, M., \& Meng, G. Y. 2014. Effects of Two Herbal Extracts and Virginiamycin Supplementation on Growth Performance, Intestinal Microflora Population and Fatty Acid Composition in Broiler Chickens. Asian-Australasian Journal of Animal Sciences, 27(3), 375382.

Sani, N., Danladi, S., Wan-Azemin, A., Rao, U. S., Mohd, K. S., \& Saravanan, D. 2015. Effects of Extracting Solvents on Total Phenolic Content, Total Flavonoid Content and Anti-Oxidant Activity of Andrographis paniculata from Kemaman, 
Malaysia. Research Journal of Pharmaceutical, Biological and Chemical Sciences, 6(3), 1397-1404.

Santoso, U. 2018. Penggunaan Daun Katuk (Sauropus androgynus) sebagai Suplemen Pakan pada Unggas. Pengaruhnya terhadap Performa Ayam. Jurnal Sain Peternakan Indonesia, 13(2), 151-156.

Santoso, U., \& Fenita, Y. 2016. The effect of Sauropus androgynus leaf extract on performance, egg quality and chemical composition of eggs. Journal of the Indonesian Tropical Animal Agriculture, 41(3), 125-134.

Saragih, D. T. 2016. Peranan daun katuk dalam ransum terhadap produksi, dan kualitas telur ayam petelur. JITP, 5(1), 11-16

Sari, A. N. 2016. Berbagai Tanaman Rempah Sebagai Sumber Antioksidan Alami. Elkawnie : Journal of Islamic Science and Technology, 2(2), 203-212

Satria, E. W., Sjofjan, O., \& Djunaidi, I. H. 2016. Respon Pemberian Tepung Daun Kelor (Moringa oleifera) pada Pakan Ayam Petelur terhadap Penampilan Produksi dan Kualitas Telur. Buletin Peternakan, 40(3), 197-202

Schiavone, A., Guo, K., Tassone, S., Gasco, L., Hernandez, E., Denti, R., \& Zoccarato, I. 2008. Effects of a natural extract of chestnut wood on digestibility, performance traits, and nitrogen balance of broiler chicks. Poultry science, 87(3), 521-527.

Setyanto, A., Atmomarsono, U., \& Muryani, R. 2012. Pengaruh penggunaan tepung jahe emprit (Zingiber officinale var Amarum) dalam ransum terhadap laju pakan dan kecernaan pakan ayam kampung umur 12 minggu. Animal Agriculture Journal, 1(1), 711-720.

Setyawan, S., MI, W. S., \& Sarjana, T. A. 2019. Pengaruh Penambahan Air Perasan Jeruk Nipis (Citrus Aurantifolia) Dalam Air Minum Terhadap Performans Ayam Broiler. Jurnal Pengembangan Penyuluhan Pertanian, 16(29), 32-38.

Setyawan, S., Sarengat, M. I., Warsono, \& Sarjana, T. A. 2019. Pengaruh Penambahan Air Perasan Jeruk Nipis (Citrus Aurantifolia) Dalam Air Minum Terhadap Performans Ayam Broiler. Jurnal Pengembangan Penyuluhan Pertanian, 16(29), 32-38

Simanjuntak, R., Santoso, U., \& Akbarillah, T. 2013. Pengaruh Pemberian Tepung Daun Katuk (Sauropus androgynus) Dalam Ransum Terhadap Kualitas Telur Itik Mojosari (Anas javanica). Jurnal Sain Peternakan Indonesia, 8(1), 65-76.

Sinurat, A. P., Purwadaria, T., Togatorop, M. H., \& Pasaribu, T. 2003. Pemanfaatan Bioaktif Tanaman sebagai "Feed Additive" pada Ternak Unggas: Pengaruh Pemberian Gel Lidah Buaya atau Ekstraknya dalam Ransum terhadap Penampilan Ayam Pedaging. JITV, 8(3) : 139-145

Suharti, S., Wiryawan, K. G., Tiuria, R., Ridwan, Y., Fitriana, S., \& Sumarni, N. 2010. Efektivitas Daun Jarak (Jatropha curcass Linn) Sebagai Anticacing Ascaridia galli dan Pengaruhnya terhadap Performa Ayam Lokal. Media Peternakan, 33(2), 108114.

Sukmasari, S., Mohd, F. N., Doolaanea, A. A., \& Rahman, M. N. A. 2018. Total phenolic content, flavonoid content, and antioxidant capacity of Syzygium. Cumini (L.) Skeels leaves grown in Wonosobo, Java, Indonesia and comparison against current findings of Syzygium cumini leaves and Syzygium polyanthum (Wight) Walp leaves. J. Pharm. Sci., 10(1) :31-35

Sulastri, E., Zubair, M. S., Anas, N. I., Abidin, S., Hardani, R., Yulianti, R., \& Aliyah A, A. 2018. Total Phenolic, Total Flavonoid, Quercetin Content and Antioxidant 
Activity of Standardized Extract of Moringa oleifera Leaf from Regions with Different Elevation. Pharmacognosy Journal, 10(6s), s104-s108.

Sulistyoningsih, M., Dzakiy, M. A., Nurwahyunani, A. 2014. Optimalisasi Feed Additive Herbal Terhadap Bobot Badan, Lemak Abdominal dan Glukosa Darah Ayam Broiler. Bioma: Jurnal Ilmiah Biologi, 3(2) : 1-16

Sultana, F., Khatun, H., \& Ali, M. A. 2016. Use of potato as carbohydrate source in poultry ration. Chemical and Biological Technologies in Agriculture, 3(30) : 1-7

Supriningrum, R., Sundu, R., \& Setyawati, D. 2018. Penetapan Kadar Flavonoid Ekstrak Daun singkil (Premna corymbosa) Berdasarkan Variasi Suhu dan Waktu Pengeringan Simplisia. JFL: Jurnal Farmasi Lampung, 7(1) : 1-6

Sutanto, A., \& Mulatmi, S. N. W. 2017. Potensi Kelayakan Bahan Pakan Organik Untuk Ayam Kampung Di Provinsi Jawa Timur. SENASPRO2.Seminar Nasional dan Gelar Produksi. 608-615

Syarifah, A., Tezan, R. and Muflihani, Y., 2015. Kandungan Nutrisi dan Sifat Fungsional Tanaman Kelor (Moringa oleifera). Buletin Pertanian Perkotaan, 5(2) : 35-44

Tiara P. A. \& Farida, Y. 2013. Total Phenolic, Flavonoids Content and Antioxidant Activity of The Ethanolic Extract of Betel Leaf (Piper betle L.). The International Conference in Nanotechnology in Jakarta, $26: 1-4$

Timbuleng, V. E., Laihad, J. T., Leke, J. R., \& Rimbing, S. C. 2015. Pengaruh penambahan tepung tomat (Solanum lycopersicum 1) terhadap kualitias internal telur ayam ras. ZOOTEC, 35(2) : 258-266

TKPI. 2019. Tabel Komposisi Pangan Indonesia. Kemenkes RI

Towaha, J. 2013. Kandungan senyawa kimia daun teh (Camellia sinensis). Warta penelitian dan pengembangan tanaman industri, 19(3):12-16

Trisna D. K., Bidura, I. G. N. G., \& Candrawati, D. P. M. A. 2014. Pengaruh Pemberian ekstrak daun kelor (Moringa ol eifera) dan bawang putih (Allium sativum) melalui air minum te rhadap penam pilan broiler umur 2-6 minggu. e-Jurnal Peternakan Tropika, 2(3) : 461-476

Tristianti, I. A. Widodo, E., Natsir, M. 2018. Pengaruh penambahan sari belimbing wuluh (Averrhoa bilimbi, L.) dalam pakan terhadap kualitas eksternal telur ayam. Jurnal Nutrisi Ternak Tropis, 1(1), 34-41

Tristianti, I. A., Widodo, E, and Natsir, H. 2018, Pengaruh penambahan sari belimbing wuluh (Averrhoa bilimbi, L.) dalam pakan terhadap kualitas eksternal telur ayam. J. Nutrisi Ternak, 1(1) : 34-41

Ulfah, M., \& Natsir, M. H. 2008. Pemanfaatan sambiloto (Andrographis paniculata Nees) sebagai aditif pakan untuk meningkatkan performan ayam pedaging. Jurnal Ilmu-Ilmu Peternakan (Indonesian Journal of Animal Science), 18(1), 11-24.

Ulupi, N. dan Ihwantoro, T. T. 2014. Gambaran Darah Ayam Kampung Dan Ayam Petelur Komersial Pada Kandang Terbuka Di Daerah Tropis. Jurnal Ilmu Produksi dan Teknologi Hasil Peternakan,2(1) : 219-223

Vidic, D., Tarić, E., Alagić, J., \& Maksimović, M. 2014. Determination of total phenolic content and antioxidant activity of ethanol extracts from Aloe spp. Bulletin of the Chemists and Technologists of Bosnia and Herzegovina, 42, 5-10.

Wahyuni, W. T., Darusman, L. K., Pitria, P., \& Rahmat, A. 2018. Analisis kadar flavonoid dan antioksidan ekstrak daun kenikir (Cosmos caudatus), rumput mutiara (Oldenlandia corymbosa), dan sirsak (Annona muricata) dengan teknik spektrometri. Analit: Analytical and Environmental Chemistry, 3(1) : 38-46. 
Wen, Gu, Tao, Cheng, Wang, \& Zhou. 2019. Effects of Ginger Extract on Laying Performance, Egg Quality, and Antioxidant Status of Laying Hens. Animals, 9(11) $: 1-9$

Widianto, B., Prayogi, H. S., \& Nuryadi, N. 2015. Pengaruh penambahan tepung buah mengkudu (Morinda citrifolia L.) dalam pakan terhadap penampilan produksi itik Hibrida. Jurnal Ilmu-Ilmu Peternakan, 25(2), 28-35.

Wiradimadja, R., Tanwiriah, W., \& Rusmana, D. 2015. Efek Penambahan Belimbing Wuluh (Averrhoa Bilimbi L.) Dalam Ransum Terhadap Performan, Karkas Dan Income Over Feed Cost Ayam Kampung. Ziraa'ah Majalah Ilmiah Pertanian, 40(2), 86-91

Wiradimadja, R., Tanwiriah, W., Rusmana, D. 2015. Efek penambahan belimbing wuluh (Averrhoa bilimbi L.) dalam ransum terhadap performan, karkas dan income over feed cost ayam kampung. Zira`ah, 40(2), 86-91

Wulandaputri, A. P. 2012. Pengaruh penambahan biji ketumbar (Coriander sativum Linn) dalam ransum terhadap performa ayam broiler di daerah tropis. Skripsi. Departemen Ilmu Nutrisi dan Teknologi Pakan. Fakultas Peternakan. Institut Pertanian Bogor.

Yadnya, T. G. B., Witariadi, N. M., \& Trisnadewi, A. A. A. S. 2014. Pemanfaatan Tepung Daun Salam (Syzygium Polyanthum Walp), Daun Pepaya (Carica Papaya), Atau Daun Katuk (Sauropus Androgynus) Dalam Ransum Yang Disuplementasi Starpig Untuk Meningkatkan Kualitas Karkas Itik Bali Afkir. Majalah Ilmiah Peternakan, 17(2) : 66-70

Yuniarti, T., Sukarno, Yuliana, N. D., Badinjanto, S. 2018. Aktivitas penghambatan ekstrak berbagai jenis bawang terhadap pembentukan blackspot pada udang vaname. Jurnal Teknologi dan Industri Pangan, 29(1) : 102-109

Yunilas, E. M., Mirwandhono, E., \& Sinaga, O. (2005). Pengaruh pemberiaan tepung temulawak (Curcuma Xanthorrizha Roxb) dalam ransum terhadap kualitas karkas ayam broiler umur 6 minggu. Jurnal Agribisnis Peternakan, 1(2), 62-66.

Yunita, R., Warnoto, W., \& Suteky, T. 2014. Pengaruh pemberian tepung daun pepaya (Carica papaya) dalam ransum terhadap performans produksi telur puyuh (Coturnix coturnix japonica). Jurnal Sain Peternakan Indonesia, 9(1), 41-50.

Zulkifli, S. A., Abd Gani, S. S., Zaidan, U. H., \& Halmi, M. I. E. 2020. Optimization of total phenolic and flavonoid contents of defatted pitaya (Hylocereus polyrhizus) seed extract and its antioxidant properties. Molecules, 25(4), 785

Zuraida, Z., Sulistiyani, S., Sajuthi, D., \& Suparto, I. H. 2017. Fenol, flavonoid, dan aktivitas antioksidan pada ekstrak kulit batang pulai (Alstonia scholaris R.Br). Jurnal Penelitian Hasil Hutan, 35(3), 211-219

Zurmiati, Z., Mahata, M. E., Abbas, M. H., \& Wizna, W. (2014). Aplikasi Probiotik Untuk Ternak Itik. Jurnal Peternakan Indonesia (Indonesian Journal of Animal Science), 16(2), 134-144.

Zusfahair, Ningsih, D. R. \& Habibah, F. N. 2014. Karakterisasi Papain Dari Daun Pepaya (Carica Papaya L.). Molekul, $9(1), 44-55$ 